NBER WORKING PAPER SERIES

\title{
THE EFFECTS OF U.S. MONETARY POLICY ON EMERGING MARKET ECONOMIES' SOVEREIGN AND CORPORATE BOND MARKETS
}

\author{
John D. Burger \\ Francis E. Warnock \\ Veronica Cacdac Warnock \\ Working Paper 23628 \\ http://www.nber.org/papers/w23628 \\ NATIONAL BUREAU OF ECONOMIC RESEARCH \\ 1050 Massachusetts Avenue \\ Cambridge, MA 02138 \\ July 2017
}

This paper, funded by the Central Bank of Chile, was prepared for the Central Bank of Chile's Twentieth Annual Conference. The authors thank Anderson Silva of the World Bank, for GEMLOC investability data; Branimir Grui of the BIS, for data on the size of local currency and USD-denominated bond markets; McKinsey Global Institute, for data on the size of global financial assets; and John Rogers, Chiara Scotti and Jonathan Wright, for their unconventional monetary policy shocks data. We also thank John Ammer, Eric Swanson, Carlos Viana de Carvalho (the discussant) and participants at the Twentieth Annual Conference of the Central Bank of Chile for their helpful comments. The views expressed herein are those of the authors and do not necessarily reflect the views of the National Bureau of Economic Research.

NBER working papers are circulated for discussion and comment purposes. They have not been peer-reviewed or been subject to the review by the NBER Board of Directors that accompanies official NBER publications.

(C) 2017 by John D. Burger, Francis E. Warnock, and Veronica Cacdac Warnock. All rights reserved. Short sections of text, not to exceed two paragraphs, may be quoted without explicit permission provided that full credit, including $\odot$ notice, is given to the source. 
The Effects of U.S. Monetary Policy on Emerging Market Economies' Sovereign and Corporate Bond Markets

John D. Burger, Francis E. Warnock, and Veronica Cacdac Warnock

NBER Working Paper No. 23628

July 2017

JEL No. F21,F3,G15

\begin{abstract}
$\underline{\text { ABSTRACT }}$
We analyze the effect of the US Federal Reserve's monetary policy on EME sovereign and corporate bond markets by focusing on two dimensions: the evolution of the structure (size and currency composition) of the bond markets and their allocations within the bond portfolios of US investors. Global factors, particularly the level of long-term US Treasury yields, matter. Across all specifications, when US long-term interest rates were low (i) EMEs issued more sovereign and private-sector local currency bonds and more private-sector foreign currency bonds and (ii) US investment in EME sovereign bonds (both local currency and USD-denominated) increased. In contrast, after controlling for the level of US long-term interest rates, measures that attempt to isolate the effects of US unconventional monetary policy are often statistically insignificant in our analysis. Local factors matter too: The local currency government bond markets in countries with stronger regulatory quality/creditor rights are larger and attract relatively more US investment. Finally, consistent with Burger et al. (2017), we find that the well-known home bias phenomenon is at least in part a home currency bias: US investors exhibit no home bias against some countries' USD-denominated bonds, whereas for local currency bonds the familiar home bias is very present.

John D. Burger

Loyola University Maryland

4501 N. Charles Street

Baltimore MD 21210-2699

jburger@loyola.edu

Francis E. Warnock

Darden Business School

University of Virginia

Charlottesville, VA 22906-6550

and NBER

warnockf@darden.virginia.edu

Veronica Cacdac Warnock

Darden Business School

University of Virginia

Box 6550

Charlottesville, VA 22906-6550

vwarnock@virginia.edu
\end{abstract}


The global environment for emerging market economy (EME) bond markets has changed dramatically over the past few decades. Local currency bond markets (LCBMs) have developed, especially in EMEs with low inflation, stronger institutions and well defined creditor rights (see Burger and Warnock 2003, 2006; Eichengreen and Luengnaruemitchai 2006, Claessens, Klingebiel and Schmukler, 2007). Some EMEs have been able to borrow globally in their local currency, which enhances financial stability by ameliorating the currency mismatches that were at the core of past crises (Goldstein and Turner, 2004). However, large inflows of foreign investment can be problematic, as most extreme capital flow episodes are driven by debt flows (Forbes and Warnock, 2013), credit booms lead to crises (Mendoza and Terrones, 2008; Gourinchas and Obstfeld, 2012; Schularick and Taylor, 2012) and large foreign investment flows into LCBMs can complicate the tasks of EME policymakers by appreciating real exchange rates, fanning asset price bubbles and intensifying lending booms. Indeed, unconventional monetary policy (UMP) by many advanced economies (AEs) may have propelled a global search-foryield strategy and contributed to a period of large and volatile inflows to EMEs. Many EME policymakers who were worried about excessive upward pressure on local currencies and indiscriminate flows enabling increasingly risky borrowing are now concerned about the possibility of an external shock (such as US monetary policy tightening) prompting a stampede for the exits.

This paper is the latest in a series of ours on EME bond markets. Our early work was primarily concerned with whether EME bond markets could ever develop and whether foreign investors would hold EME local currency bonds as opposed to only holding EMEs' foreign currency denominated bonds. Burger and Warnock (2006, 2007) found that, counter to the "original sin" literature, policies and laws indeed matter, as EMEs with stable inflation rates and strong creditor rights have more developed local bond markets, rely less on foreign currency-denominated bonds and can attract US investors. Our subsequent work focused in part on whether the global financial crisis put an end to EMEs' bond market 
development and foreigners' interest in EME local currency bonds. Burger, Warnock and Warnock (2012), focusing on the period from 2001 to the end of 2008 — when the crisis had already begun — find that policies and laws that helped improve macroeconomic stability and creditor rights enabled EME local currency bond markets to grow substantially and also provided US investors with attractive returns. US investors responded by sharply increasing their holdings of EME local currency bonds, especially in EMEs with investor-friendly institutions and policies. Burger, Sengupta, Warnock and Warnock (2015) extend that analysis in a panel dataset from 2006 through 2011, focusing on US investors' reallocations within their international bond portfolios. They note that the steady increase in US investors' allocations towards EME local currency bonds, which was unabated by the global financial crisis and even accelerated after the crisis, was due in part to global 'push' factors, such as low US long-term interest rates and subdued risk aversion or expected volatility. But also evident was investor differentiation among EMEs, with the largest reallocations going to those EMEs with strong macroeconomic fundamentals, such as less volatile inflation and more positive current account balances. Finally, Burger, Warnock and Warnock (2017), using a panel dataset from 2006 to 2015, find a home currency bias: Not only do factors associated with greater (or less) cross-border investment in bonds differ by currency denomination, but also the everpresent home bias actually disappears in some cases when bonds are denominated in the investor's currency.

In this paper, we analyze bond markets using a panel dataset similar to that in Burger, Warnock and Warnock (2017), spanning the period 2007 to 2015. Currency denomination, as in all of our bond market papers, is an important aspect of our analysis, but unlike in our earlier work, the focus here is squarely on sectoral aspects of EME bond markets. In particular, we assess the development of EME sovereign and corporate bond markets, both local currency and foreign currency and attempt to understand what drives US investors' portfolios in those markets. 
We find that the structure of EME bond markets has generally continued to improve over the 2007 to 2015 period, as many EMEs have lessened their reliance on foreign currency bonds. That trend has reversed slightly in recent years, in particular because of increased private-sector issuance of foreign currency denominated bonds. Nevertheless, the share of EME bonds denominated in the local currency is markedly higher than a decade ago and time-fixed effects in our regressions indicate that, after controlling for local variables, over the 2007-2015 period there has been a trend toward larger sovereign local currency bond markets and larger private foreign currency bond markets. It is this latter trend that creates the recent decline in the share of private bonds denominated in local currency. ${ }^{1}$ Regarding the determinants of bond market development, we find that local factors matter: countries with better macroeconomic stability (i.e., lower inflation volatility) have larger sovereign local currency bond markets and a greater share of private local currency denominated bonds; stronger regulatory quality/creditor rights are associated with larger sovereign local currency bond markets and a greater share of local currency denominated bonds (both sovereign and private issued); and countries with more positive current account balances have larger bond markets (both local currency and foreign currency denominated, and especially private-sector issued bonds) and a greater share of bonds denominated in local currency. Interestingly, larger economies in our sample have smaller foreign currency bond markets and a larger share of local currency bonds. US conditions and policies also influence EME bond markets: (a) local currency (both sovereign and private) and private foreign currency bond markets increased in size when US yields, especially the non-large scale asset purchase portion (non-LSAP), were lower, and (b) EME bond markets grew most during periods of lower CBOE Volatility Index (VIX). Controlling for the level of US longterm interest rates, we fail to find robust evidence for an additional impact of UMP on EME bond market

\footnotetext{
${ }^{1}$ For this study, a local currency bond is denominated in the currency of the country of residence of the issuer, in keeping with residence-based international accounts. A recent focus on the ultimate nationality of the issuer - for example, when a Chinese firm issues a yuan-denominated bond through an off-shore subsidiary (see, for example, McCauley et al., 2013) - is relevant, but beyond the scope of our study.
} 
development, as across three UMP proxies there is limited and mixed evidence linking US unconventional monetary policy and bond market development.

We also examine the evolution of US investors' EME bond portfolios, employing data on country-level holdings (by currency and sector of issuer) built from high-quality security-level data. While holdings of private-sector local currency bonds remain quite small (the data appear to indicate that EME corporates must issue in US dollars to attract a meaningful amount of US investment), holdings of sovereign issued local currency bonds and private-issued USD-denominated bonds have increased significantly over the past decade. For sovereign local currency bonds, we find that US investment is greater in EMEs with more positive fiscal balances, higher yields, greater regulatory quality and creditor rights and stronger trade ties with the US. Some global factors also matter. For example, lower US longterm interest rates and a lower VIX are associated with increased investment in EME sovereign local currency bonds. However, results for UMP proxies were mixed, including some (but not much) evidence that the LSAP-induced fall in US rates was associated with increased investment in EME sovereign local currency bonds. Overall results for these bonds are consistent with the classic result of low US rates being associated with a surge in investment in EMEs. From our analyses of US cross-border investment in USDdenominated bonds, we find investment was greater in EMEs with stronger regulatory quality and creditor rights, lower inflation volatility and lower yields. We also find evidence that lower US interest rates are associated with increased investment in USD-denominated sovereign bonds, but global push factors do not appear important in determining investment in EME private-sector bonds.

In addition to being related to our series of papers on EME bond markets, as discussed above, this paper is related to academic literature in four respects. First, on bond market development, it adds to Burger and Warnock (2006), Claessens et al. (2007) and many others (to be discussed in Section 3). Second, it contributes to the literature on relationships between international portfolios and global and 
local factors. For example, Calvo et al. (1993) noted the importance of global factors such as US interest rates in explaining capital inflows, and Chuhan et al. (1998) made the important contribution of separating different types of flows and found that global factors were important in explaining capital inflows, but country-specific developments were at least as important. Many subsequent papers confirmed points made by those two papers. A recent example, Fratzscher (2012), using weekly fund flows data, found that global factors were the main drivers of capital flows in the midst of the recent crisis, but that country-specific determinants were dominant in the years immediately following the crisis. Third, our paper is also directly related to work on international investment in bonds_-including Lane (2006) and Fidora et al. (2007) and on US investors' local currency bond portfolios_-Burger and Warnock (2007); Burger, Warnock and Warnock (2012). Fourth, a closely related but separate literature looks at cross-border banking flowssee, for example, Blank and Buch (2007) and Hale and Obstfeld (2016).

Our assessment of EME bond markets - their size, structure and international investment—starts in the next section with a discussion of considerations about existing data on bonds outstanding and bond holdings. Section 2 describes the three ways UMP proxies enter our regression analysis. In Section 3, we describe and assess the evolution of EME markets. In Section 4, we assess US investors' EME bond portfolios. Section 5 concludes.

\section{Bonds Outstanding and Bond Holdings Data}

\subsection{Working Dataset}

Our assessment of the development of EME bond markets demands a careful appraisal of available datasets. We consider the following four points: First, the currency denomination of bonds should be identified for both bonds outstanding and cross-border bond holdings - the location of the issuer is not an accurate proxy for the currency denomination of bonds - so that we can examine the development of local

currency denominated bonds against foreign currency denominated ones, as well as investors' allocations 
within the two (local and foreign currency). Second, we are interested in revealing any differences in trends between sovereign issued bonds and private-sector issued bonds, and so we require data disaggregated by sector (public v. private). Third, we choose a class of investors, namely, those residing in the US, for which consistent and complete data are available. Fourth, we obviously need data through time.

Given the above requirements, our working dataset for this paper consists of annual data from 2007 to 2015 on 15 EMEs, assembled from two main sources: portfolio data from US Treasury comprehensive benchmark surveys and bond market data from the recently redesigned debt securities datasets of the Bank for International Settlements (BIS). Local currency denominated debt is clearly identified in the Treasury data and, in the BIS data, it is the sum of the long-term debt component of "domestic debt" and the local currency/local issuer portion of "international bonds". Overall, our dataset allows us to separately analyze bonds by sector of the issuer (sovereign or private) and by currency denomination (local currency and foreign currency, including a separate entry for USD-denominated bonds). We consider this dataset appropriate for our study; but, it also poses significant challenges, which we outline below.

\subsection{The Amount of Bonds Outstanding}

Before 2012, data that identified the currency denomination and issuer of bonds were available from BIS for more than 40 countries, including over 20 EMEs. The relevant data on debt securities and international bonds statistics formed the BIS Quarterly Review "Table 16A: Domestic debt securities, by sector and residence of issuer" and "Table 14B: International bonds and notes - all issuers, by residence of issuer". Domestic debt was defined by the BIS as local currency bonds issued by locals in the local market (i.e., not placed directly abroad), while international bonds were bonds issued either in a different 
currency or in a different market. It was possible to back out data on bonds (debt securities with original maturity over one year $)^{2}$ placed either domestically or internationally, as well as to identify the issuer's residence, the currency denomination of the bonds and the type of issuer (sovereign or private). Burger, Sengupta, Warnock and Warnock (2015), using this BIS dataset, were able to include 21 EMEs and 23 AEs. However, this dataset was discontinued and is thus available only through 2011 , and is possibly inconsistent with the new dataset based on new methodology that the BIS established in 2012 (see Gruić and Wooldridge, 2012).

In the new BIS dataset (with 2012 definitions) that we use in this paper, "international bonds" are largely the same as in the discontinued pre-2012 dataset described above. The challenge with this new dataset is that central banks of some countries have opted to report data that sum together domestic and international debt. We argue that, even for an aggregated analysis, combining domestic and international debt hampers analysis. For analyses that explicitly require splits on currency and maturity —a split that used to be readily available because the international portion was built up from security-level data and the domestic portion was assumed (by definition) to be denominated in the local currency — aggregated debt data presents a severe limitation.

\subsection{Bond Holdings}

International bond portfolio data must identify the currency denomination of the underlying bonds, because the location of the issuer does not indicate the currency denomination of the bonds. One dataset that identifies currency denomination is available for a particular set of investors: US resident investors.

\footnotetext{
${ }^{2}$ The split between bonds/notes and short-term paper can be important. Consider, for example, Brazil. A large proportion of Brazilian debt securities are short-term; see Leal and Carvalhal da Silva (2008) for a detailed analysis. In the old BIS database, Brazilian debt securities were broken out by maturity (and currency denomination), and it showed that, as of end2011, about $\$ 1$ trillion of its $\$ 1.5$ trillion in domestic debt securities were short-term instruments (e.g., money market). Using the old dataset, one can omit Brazilian short-term instruments and focus on Brazilian domestic long-term debt securities (which totaled $\$ 0.5$ trillion at end-2011).
} 
Data on US holdings of foreign bonds have been obtained from periodic, comprehensive security-level benchmark surveys conducted by the US Treasury Department, the Federal Reserve Bank of New York and the Board of Governors of the Federal Reserve System. The security-level holdings data are not available to researchers outside the Federal Reserve Board, but the country-level aggregates (with currency and sector breakdown) that are built from the security-level data are available for over 100 countries and provide a clean annual dataset beginning in $2007 .{ }^{3}$ These holdings data also constitute the official US data on international positions; for example, the figure for international bonds in the International Investment Position report issued by the Bureau of Economic Analysis is formed by aggregating the survey's security-level information.

The data based on the granular security-by-security data are aggregated according to the currency denomination of a bond, the country residence of its issuer and the sector (sovereign or private) of the issuer. Starting with year-end 2007 data, the data are posted on the Treasury website, in a report with a table labeled as "US holdings of foreign long-term debt securities, by country and sector of issuer, denominated in US dollars and in local currency."

Although in our analysis we are forced, by limited data availability, to focus on US investors' cross-border bond holdings (and not investors across a number of countries), it is sufficiently rich because US investors are a large group for which we have high-quality, publicly available data. And to reiterate, US investors' bond holdings are captured at the security level, so the exact nature of the bond is known to

\footnotetext{
${ }^{3}$ Note that, while for foreign currency bonds we limit our portfolio analysis to USD-denominated bonds, U.S. investors' holdings of third-currency bonds (i.e., neither in USD, nor in the issuer's currency) are extremely small, amounting to only $2.3 \%$ of their foreign bond portfolio in 2011.

${ }^{4}$ For more detail, see, for example, U.S. Department of the Treasury et al. (2008), or the Griever, Lee and Warnock (2001) primer. For the exact table we use, see, for example, Table 29 from U.S. Department of the Treasury et al. (2008) or Table A11 from U.S. Department of the Treasury et al. (2016). Note that we alter the underlying Treasury data in two ways. One, we leave true zeros as zeros, but we replace asterisks, which indicate that U.S. holdings are greater than zero but less than $\$ 500,000$, with $\$ 250,000$. Two, there are instances when, for a particular split of the data, reported U.S. holdings are greater than the amount outstanding; in these cases, we set holdings equal to the amount outstanding.
} 
the data clearinghouse (i.e., Treasury, NY Fed and the Federal Reserve Board) and, therefore, this enables the production of publicly available reports on bonds by various classifications (currency, sector, etc.)

\section{Unconventional Monetary Policy in the Empirical Model}

Several proxies for unconventional monetary policy (UMP) are available, although for our purposes no one method seems to be superior over the rest. ${ }^{5} \mathrm{We}$ therefore use three approaches for UMP. First, following Ahmed and Zlate (2014), we decompose the 10-year Treasury yield into two components: one that may be due to LSAPs (usi10_LSAP) and the yield estimated in the absence of LSAPs (usi10_nonLSAP). Specifically, in a first-stage regression, we regress Treasury yields on one-quarter ahead Fed net asset purchases (since the QE programs were announced ahead of implementation) over the period from 2002:Q4 to 2016:Q2, and then we compute the LSAP component of yields as beta*LSAP. ${ }^{6}$ The remaining yield is the non-LSAP component. For the period prior to the first QE program, we set the LSAP component to zero. The results suggest that, on average, $\$ 100$ billion in LSAPs in a quarter would decrease yields by 37.5 basis points (bps), in line with the Ahmed and Zlate (2014) estimate of 31 bps and roughly consistent with other estimates in the literature. For example, the D'Amico and King (2013) event study estimated a persistent downward shift in yields averaging $30 \mathrm{bps}$, and the VAR estimates of Bhattarai, Chatterjee and Park (2015) suggest $\$ 100$ billion in LSAPs would have a 25 basis point effect

\footnotetext{
${ }^{5}$ In the literature, a number of UMP proxies have been employed; see Ahmed and Zlate (2014) for a discussion focused on LSAPs. For example, an indicator variable has been used to mark initial announcements and implementation periods of the first three rounds of LSAPs; see Gagnon et al. (2010), Krishnamurthy and Vissing-Jorgensen (2011) and Bauer (2012). See also D'Amico and King (2013), Wright (2012), Hamilton and Wu (2012), Bauer and Rudebusch (2014), Rogers et al. (2014) and the Fawley and Neely (2013) narrative account of the LSAPs of four major central banks. Another technique is to use a VAR-based approach to assess the effects of quantitative easing (QE); see Wright (2012), Baumeister and Benati (2013), Gambacorta et al. (2014) and Bhattarai, Chatterjee and Park (2015). Swanson (2016) uses techniques from Gurkaynak, Sack and Swanson (2005) to estimate separate forward guidance and LSAP effects. Other work on the international effects of U.S. QE policy include Glick and Leduc (2012, 2013), Chen et al. (2012) and Bauer and Neely (2014); Eichengreen and Gupta (2015), Aizenman et al. (2016) and Bowman et al. (2015); Tillmann (2014) estimates of the QE effects on the aggregate data of EMEs; and the Ahmed and Zlate (2014), Ahmed et al. (2016), Dahlhaus and Vasishtha (2014) and Lim et al. (2014) analyses of the QE effects on capital flows to EMEs.

${ }^{6}$ LSAP is the change in the size of Federal Reserve securities holdings (from the Federal Reserve Statistical Release H.4.1) scaled by GDP.
} 
on impact. Figure 1 shows the actual 10-year Treasury yield (thick line), our estimate of what the 10-year yield would have been without LSAPs (thin line) and LSAP scaled by GDP (bars, right-hand scale). Table 1 shows the two series from the decomposition that enter our annual regressions: an estimate of what the US 10-year yield would have been without LSAPs (usi10_nonLSAP) and the effect of LSAPs on the US 10-year yield (usi10_LSAP). The LSAP effect averages 31 bps per year from 2009 through 2014 with peaks in 2010 and 2013.

The second approach augments the first by adding a direct measure of the amount of LSAPs scaled by GDP (lsap_flow_gdp) in regressions that also include the 10-year interest rate.

The third approach uses well-identified UMP shocks to the 10-year interest rate, as calculated by Rogers, Scotti and Wright (2016), henceforth RSW, which updates Rogers et al. (2014). Specifically, RSW use high-frequency financial market data around Federal Reserve announcements (FOMC statements as well as governors' speeches) to help identify monetary policy shocks in a VAR setting. We use the RSW shock to the 10-year rate-the change in 10-year Treasury rates within a 2-hour window of announcements - and, at the same time, also include the level of the 10-year Treasury interest rate (which itself captures some of the impact of unconventional monetary policy).

We are agnostic on the many ways to proxy UMP; we therefore utilize the three approaches described above and attempt to discern effects that are robust to the choice of a proxy.

\section{Bond Markets in Emerging Market Economies}

\subsection{Structure of EME Sovereign and Corporate Bond Markets}

We start by presenting salient features of EME sovereign and corporate bond markets, specifically, their size and structure. For consistency, in descriptive tables or figures that present aggregates, we include 
only the 13 EMEs for which we have complete data for 2009 and 2015: Chile, Colombia, Mexico and Peru; Korea, Malaysia, Pakistan, Philippines and Thailand; and Israel, Russia, South Africa and Turkey.

Table 2 presents information on 13 EME bond markets and shows that, over the period 2009-2015, local currency bond markets grew from $\$ 2289$ billion to $\$ 3281$ billion, just over half of which were issued by sovereign entities. The size of local currency bonds, measured as a percent of the country's GDP, increased modestly from $42 \%$ to $46 \%$, and their weight in the global bond market increased from $2.7 \%$ to 3.5\%. Foreign currency denominated bonds - most of which are issued by the private sector-also increased, from $\$ 436$ billion in 2009 to $\$ 851$ billion in 2015 , increasing from $8.0 \%$ to $11.8 \%$ of national GDP and nearly doubling their weight in the global bond market (from $0.5 \%$ to $0.9 \%$ ). Of the foreign currency denominated bonds, most are USD-denominated ( $\$ 714$ billion out of $\$ 851$ billion in 2015). Overall, most EME bonds are denominated in the local currency; in 2015, 87\% of sovereign bonds and $72 \%$ of private-sector bonds were denominated in the local currency.

The evolution of EME sovereign and corporate bonds markets is plotted in Figures 2a-2e. We see the stark predominance of local currency bonds over USD-denominated bonds and a milder predominance of sovereign over private bonds (Figure 2a). Though smaller in size, USD-denominated private-sector bonds have rapidly grown, more than doubling between 2009 and 2015 . Bonds outstanding by country, plotted in Figures 2b-2e, help uncover any regional trends, while showing differences across countries within a region. As a share of GDP (Figure 2b), local currency sovereign bond markets increased smartly since 2007 in many Asian and Latin American EMEs, but less so in other countries. In contrast, trends in the development of many private-sector local currency bond markets are less discernible (Figure 2c). Further, local currency share-the share of local currency bonds in all bonds-is generally high for sovereign bonds (Figure 2d), but lower and even declining for private-sector bonds (Figure 2e). This last 
point - the decline in local currency share of private bonds - is due to the doubling of private-sector foreign currency bonds evident in Figure 2a.

\subsection{The Determinants of the Size and Structure of EME Bond Markets}

Why do some EMEs have larger local currency bond markets than others? In Burger, Warnock and Warnock (2012), we assessed the size of local currency bond markets in 2008 and found that EMEs with lower inflation volatility and stronger legal rights have more developed local bond markets. In Burger and Warnock (2006), the findings were similar; economies can (and have) put in place institutions and policies that foster the development of debt markets. Economies with better inflation performance (an outcome of creditor-friendly policies) have more developed local bond markets, both private and sovereign and rely less on foreign currency denominated bonds. Creditor-friendly laws matter. Stronger rule of law is associated with deeper local bond markets and countries with stronger creditor rights are able to issue a larger share of bonds in their local currencies.

With an annual panel dataset spanning 2007 to 2015, we refresh our analysis on the size and currency composition of bond markets. Similar to Burger and Warnock (2006) and Claessens et al. (2007), we employ three measures of bond market development, each defined by sector (sovereign and private) as follows: the ratio of the size of the local currency bond markets to GDP, the ratio of the size of the foreign currency bond markets to GDP and the share of the country's outstanding bonds denominated in the local currency (local currency share).

Explanatory variables include regulatory quality, creditor rights, fiscal and current account balances, country size, GDP growth rate, the extent of trade with the US, a bond-specific measure of capital account openness and inflation volatility. Specifically: 
- $\quad r e g c r$ is a measure of regulatory quality and creditor rights, calculated as a weighted average of the Regulatory Quality Index from the World Bank's World Governance Indicators and the Legal Rights Index from the 'Getting Credit' section of the World Bank's Doing Business report. We construct a composite measure with twice the weight on regulatory quality, according to the GEMLOC Investability Indicator Methodology (Markit 2013). ${ }^{7}$ We recast the indicators to have values from 0 to 1 -instead of from 0 to 100 - to easily interpret the regression coefficients.

- caopen is a Markit (2013) de jure measure of the openness of a country's local currency bond market to foreign investment, with higher scores indicating that a bond market is more open to cross-border investment. From the update of Markit (2013), we use the November observation of "Capital Control, Convertibility and Access" for each country and year and merge with the Burger et al. (2015) estimates for 2006 and 2007. We assume top scores (i.e., completely open) for South Korea (which enters the Markit dataset in 2011 with score of 100) and Israel and Singapore (which are not in the Markit sample). We recast caopen to range from 0 to 1.

- $\quad c a \_g d p$ and $f b a l$ (current account balance and fiscal balance, both scaled by GDP) are from IMF's IFS as reported in Haver Analytics.

- infvol, inflation volatility, is computed on a rolling basis using three years of quarterly data (from the IMF's International Financial Statistics (IFS) data as reported in Haver Analytics).

- growth is calculated as the three-year average growth rate in real GDP per capita (from IMF's IFS data as reported in Haver Analytics).

- $n o m g d p$ is the log of nominal GDP in USD.

\footnotetext{
${ }^{7}$ The regulatory quality index measures a government's ability to formulate and implement sound policies and regulations that promote private sector development, while the creditor rights index measures the degree to which collateral and bankruptcy laws protect the rights of borrowers and lenders.
} 
- trade_gdp is bilateral imports and exports between the US and the foreign country, scaled by the respective countries' nominal GDP (source: IMF).

- For global variables, we include the VIX, as well as several proxies for unconventional monetary policy and US 10-year Treasury yields (as described in Section 2 and presented in Table 1).

In our regressions, we use an annual panel dataset that spans the period 2007 to 2015 and includes 15 EMEs. In all, we have 123 observations, as due to data limitations some EMEs enter the panel later than $2007 .{ }^{8}$ We report our results in Table 3 for sovereign bonds and for private-sector bonds using three measures: local currency scaled by GDP, foreign currency scaled by GDP and share of local currency in total. Constants are included but not reported. Estimates are calculated using panel-feasible generalized least squares (FGLS), which allows for heteroscedastic error structures and different autocorrelation coefficients for each country. Wald tests (not reported) show that the explanatory variables are always jointly significant.

First, in Table 3a we include time-fixed effects (but not global factors) to capture the impact of global forces on EME bond markets during each year in the sample; coefficients for 2008 to 2015 are reported and should be interpreted relative to 2007. The strongest results (in a statistical sense and also robust across specifications) are as follows:

- Countries with stronger regulatory/creditor rights have larger local currency sovereign bond markets and a greater share of bonds denominated in local currency (both sovereign and private).

- $\quad$ Countries with stronger current account balances have larger local currency bond markets (and higher local currency share).

\footnotetext{
${ }^{8}$ Ten countries have data for all 9 years. In addition, Chile enters in 2008; Mexico and Pakistan, in 2009; Hungary, in 2010; and India, in 2011. We lose 3 observations in the final column of Table 3, because Pakistan had no reported private-sector bonds.
} 
- $\quad$ Trade with the US matters for private-sector bonds, but negatively impacts sovereign bonds. While we cannot see the underlying firm-level data, it could be that corporates that trade a lot with the US also issue more bonds (some of which are USD-denominated).

- Capital account openness matters only for foreign currency private bonds. Macroeconomic stability (infvol) impacts only local currency sovereign bonds.

- The impact of country size varies across the specifications: Larger countries in our sample have smaller foreign currency bond markets and a larger share of local currency bonds.

- The time effects are often positive and significant for sovereign local currency bonds and foreign currency private bonds and often negative for the local currency share of private bonds. In other words, after controlling for other variables, over the 2007 to 2015 period there has been a trend toward larger sovereign local currency bond markets and larger private foreign currency bond markets (the latter trend leading to a decline in the share of all private bonds denominated in local currency).

In Tables 3b-3d, we include global push variables and omit the time-fixed effects. The impact of country-specific macroeconomic conditions and policies is broadly similar to the analysis in Table $3 \mathrm{a}$. In addition, we see that US yields and global risk conditions matter. EME local currency (both sovereign and private) and foreign currency private bond markets increased in size when the non-LSAP component of the 10-year Treasury was lower (Table $3 b$ ). We also find evidence that EME bond markets grew most during periods of lower VIX. Further, there is no robust evidence showing an independent impact of UMP - that is, above and beyond what is embedded in long-term Treasury yields — on the size and currency composition of EME bond markets. Across the three UMP proxies, there is limited and inconsistent evidence linking Fed policy and bond market development (beyond the ever-present US long- 
term interest rate effect). That said, we do find some evidence suggesting that UMPs that lower US long rates are associated with increased EMEs' private-sector issuance in US dollars.

\section{US Investors' International Bond Portfolios}

\subsection{Analyzing US Investors' Portfolios: Measure}

The dependent variable in this analysis is the Ahmed, Curcuru, Warnock and Zlate (2016) measure of portfolio weights - the normalized relative weight.$^{9}$ Relative weight is simply a country's weight in US investors' portfolio relative to its weight in a benchmark portfolio. Specifically, country $i$ 's relative portfolio weight in US portfolios is the ratio of its weight in US investors' portfolio to its weight in the global market. Relative weight can be defined as:

$$
\operatorname{Re}_{\mathrm{Lgt}}{ }_{i}^{U S}=\frac{\omega_{i, U S}}{\omega_{i . m}}=\frac{H_{i}^{U S} / \sum_{i} H_{i}^{U S}}{\operatorname{MCap}_{i} / \sum_{i} \operatorname{MCap}_{i}}
$$

where $H_{i}^{U S}$ is defined as US investors' holdings of country $i$ 's bonds and $\sum_{i} H_{i}^{U S}$ represents the global portfolio of bonds held by US investors, while $M C a p_{i}$ is the market capitalization of country $i$ 's bond market and $\sum_{i}$ MCap $_{i}$ is the market capitalization of the global bond market. If the portfolio weight assigned to a particular bond market equals its weight in the global bond market, the relative weight for that market is one. In reality, US investors' relative portfolio weights are often far less than one- this is

\footnotetext{
${ }^{9}$ Relative weight is consistent with an international Capital Asset Pricing Model (CAPM)-based model of international portfolio allocation as presented in Cooper and Kaplanis (1986). That model, described in some detail in Holland et al. (2016), includes country-specific proportional investment costs representing both explicit and implicit costs of investing abroad and is designed to optimize an investor's allocation of wealth among risky securities in $n$ countries in order to maximize expected returns net of costs. If there are no costs to investing, the allocation collapses to the global market capitalization allocation; that is, the investor allocates his wealth across countries according to market capitalizations. If costs are non-zero and non-uniform, allocations deviate from market weights. The higher the costs in a particular foreign market, the more severely underweighted that country will be in the investor's portfolios. The international CAPM, therefore, provides a theoretical underpinning for our focus on relative weight.
} 
one dimension of the well-known home bias in asset holdings - because over 90 percent of US investors' bond holdings are issued by US entities. That said, for some asset classes - such as bonds denominated in the investor's currency-relative weights can and sometimes do exceed one (Burger, Warnock and Warnock 2017).

Relative price changes will cause movements in Relative Weight even if investors do not alter their positions. This relative price effect can be removed through the simple normalization of dividing the relative weight from equation (1) by the relative weight for the home market:

norm RelWgt $=\frac{\omega_{i, U S}}{\omega_{i, m}} / \frac{\omega_{U S, U S}}{\omega_{U S, m}}$

This normalized relative weight is shown in Ahmed et al. (2016) to isolate portfolio reallocations that are independent of relative price changes and are consistent with the Bekaert and Wang (2009) adjustment of scaling by the source country's home bias. In our panel regressions, we use normalized relative weight, a measure of portfolio allocations that omits passive portfolio changes due to relative price changes.

\subsection{Evolution of EME Bond Holdings}

The EME local currency bond portfolio of US investors grew dramatically from $\$ 20$ billion in 2009 to $\$ 72$ billion in 2015 (lower panel of Table 4). EME local currency bonds were $2.7 \%$ of the global bond market in 2009 and grew to $3.5 \%$ in 2015 . US holdings increased even faster: US investors held $0.87 \%$ of outstanding EME local currency bonds in 2009 and this increased to $2.2 \%$ by 2015 . Because the weight of EME local currency bonds in US portfolios has increased relative to their weight in the global bond market, the relative weight measure for EME local currency bonds in US investors' portfolios more than doubled over this period, from 0.029 in 2009 to 0.070 in 2015. 
Holdings of USD-denominated bonds issued by EMEs are substantially larger at $\$ 73$ billion in 2009, which increased to $\$ 152$ billion by 2015 and US investors hold a slightly higher percentage of outstanding EME USD-denominated bonds (20.5\% in 2009, 21.3\% in 2015). Indeed, the weights of EME USD-denominated bonds in US bond portfolios $(0.29 \%$ in $2009,0.51 \%$ in 2015$)$ are not too dissimilar from their weight in the global bond market ( $0.4 \%$ in $2009,0.8 \%$ in 2015$)$, so US investors' relative weight on EME USD-denominated bonds are much closer to one (0.68 in 2009, 0.67 in 2015).

US holdings of EME bonds, levels by currency and sector, are presented in Figure 3, which can be compared with the amount of bonds outstanding from Figure 2a. Quite apparent is the fact that the ratio of local-to-USD bonds is much smaller in US portfolios than in bonds outstanding. Most EME bonds are denominated in the local currency, but most US holdings (especially of private-sector bonds) are in USD. In fact, whereas US investors hold roughly equal amounts of local currency and USD-denominated sovereign bonds, US holdings of private-sector EME local currency bonds are so low, that it appears that EME corporates must issue in USD to reach US investors.

Regional aggregates (Figure 4) add insight into the stylized fact presented in Burger, Warnock and Warnock (2017) that home bias is, to some extent, a home currency bias. In each graph in Figure 4, there are two thick lines; the higher of the two is the relative weight for USD-denominated bonds, whereas the lower thick line is for local currency bonds. As in Burger et al. (2017), relative weights for USDdenominated bonds are always much greater than for local currency bonds. Also shown are the sectoral splits. That EME corporates must issue in USD to reach US investors is evident from the private-sector USD relative weights being near zero. Relative weights for sovereign local currency bonds are also quite low, but nowhere near zero. And relative weight for USD bonds, whether sovereign or corporate, is quite high. 


\subsection{Empirical Analysis of US Investors' Foreign Bond Portfolios}

Over the past decade, US investors have significantly increased their cross-border holdings of EME bonds. We use a common framework to analyze the evolution in US investors' country-specific relative portfolio weights - that is, their portfolio weights relative to a global benchmark — for bonds split by currency and sector. Our annual panel dataset of US investor relative portfolio weights includes 15 destination countries over the 2007 to 2015 period. ${ }^{10}$ For explanatory variables, in addition to the countryspecific factors from Table 3, we include another "pull" factor, yield, to proxy for expected return. ${ }^{11}$ The other macroeconomic indicators are shown in Table 3 and here represent factors that likely impact the attractiveness of an economy as a destination for cross-border bond investment. Inflation volatility (calculated as a rolling, trailing 12-quarter standard deviation) is included as a proxy for the uncertainty of ex-ante real returns-increased inflation volatility will also lead to more volatile nominal bond yields, thus increasing reinvestment risk. We include the current account to GDP ratio as a proxy for financial imbalances. A country running a current account deficit must attract capital flows; if those inflows do not materialize, adverse financial market outcomes (such as currency depreciation and/or a spike in bond rates) are likely to occur. We also include the 3-year average growth rate in real GDP per capita as an indicator of the vigor of the destination economy. Our primary institutional variable (our measure of regulatory quality and creditor rights) and our de jure measure of the openness of a country's local currency bond market to foreign investment are described in Section 3. For global "push" factors, we include the VIX volatility index (which measures variation in expected volatility and risk appetite, and which we divide by 100 for readability of regression coefficients) and the three measures of US long rates and US unconventional monetary policy discussed in Section 2.

\footnotetext{
${ }^{10}$ The number of destination countries is limited not by the holdings data, but by data on the size and composition of bond markets and by explanatory variables.

${ }^{11}$ Yield, expressed in basis points, is the annual average of monthly bond yields (yield-to-maturity from the J.P Morgan GBI indexes). JPMorgan provided yield data through 2013; we gathered 2014 and 2015 data from the Bloomberg.
} 
We present results for US cross-border investment in local currency bonds in Table 5 and in USD-denominated bonds in Table 6. In each case, we split by sector with sovereign bonds in Panel a and private-sector bonds in Panel b. In both tables, we include either time-fixed effects (column 4) to show the impact of global forces on bond allocations over time without having to specify the precise nature of the global variables, or specific global "push" factors (columns 1-3). For the time effects, coefficients for 2008 to 2015 are reported and should be interpreted relative to 2007.

\subsubsection{Panel Results for Local Currency Portfolio Allocations}

The results for investment in local currency bonds (Table 5) show a stark contrast between sovereign and private-sector bonds. Much fewer explanatory variables are significant for private-sector bonds (Panel b), but this is not surprising given the minimal investment by US investors in local currency bonds issued by the private sector in EMEs. For sovereign bonds (Panel a), US investment is greater in countries with more positive fiscal balances, higher yields, greater regulatory quality and creditor rights and stronger trade linkages with the US. The time-fixed effects indicate that, after controlling for countryspecific factors, US investors increased their allocations to EME local currency sovereign bonds during the 2010 to 2015 period. When including specific global factors (columns 1-3), results suggest that lower US interest rates and lower VIX are associated with increased investment in local currency sovereign bonds. We get mixed results when we bring in unconventional monetary policy, but we do find that the LSAP-induced fall in US rates was associated with increased investment in EME local currency sovereign bonds.

In summary, the results for EME sovereign local currency bonds in Table 5 are consistent with the classic result of low US rates being associated with a surge in EME investment, therefore providing a plausible channel through which US conditions could have contributed to the appreciation of EME currencies (and also providing support to currency war claims). 


\subsubsection{Panel Results on USD-denominated Portfolio Allocations}

We analyze US cross-border investment in USD-denominated bonds and report our results in Table 6 for sovereign bonds (Panel a) and private-sector bonds (Panel b), including country-level "pull" factors and either time-fixed effects (column 4) or global "push" factors (columns 1-3). The time-fixed effects for USD-denominated sovereign bonds are positive and significant for many years between 2009 and 2014. For private-sector USD-denominated bonds the time-fixed effects are all negative and usually statistically insignificant. Investment in USD-denominated sovereign EME bonds was greater in countries with stronger regulatory quality/creditor rights, lower inflation volatility and lower yields. For USDdenominated bonds issued by the private sector in EMEs, investment is greater in smaller economies and in those with greater trade linkages with the US For global factors, there is a sharp contrast in the impact on US investment in USD-denominated sovereign v. private-sector bonds. Low US interest rates and lower VIX are associated with increased relative weights on USD-denominated sovereign bonds, but we fail to find a significant impact of these global push factors on relative weights for the growing stock of USD-denominated private-sector bonds.

\section{Conclusion}

Our assessment of EME sovereign and corporate bond markets suggests that local factors matter. For example, countries with stronger regulatory quality/creditor rights have larger sovereign issued local currency bond markets and also attracted relatively more US investment into their sovereign bonds. But a longstanding global factor - the level of US long-term interest rates-is also important in much of our analysis: We find strong evidence that, when US long rates were low, (1) EMEs issued more sovereign and private-sector local currency bonds and more private-sector foreign currency bonds, and (2) US investment in EME sovereign bonds (both local currency and USD-denominated) increased. 
We use three methods to isolate the effects of unconventional monetary policy of the US, but we find UMP was rarely important. The low-frequency (annual) data we use is potentially hiding important effects; for example, shocks in June could be undone by December. Still, the contrast between the importance of US long-term rates and UMP is striking.

The interesting stylized fact from Burger et al. (2017) that the home bias is, at least in part, a home currency bias-US investors exhibit no home bias against some countries' USD bonds — is also evident here. Our sectoral analysis provides additional insight. Relative investment weights, whether for sovereign or corporate bonds, are always substantially higher for USD-denominated bonds than local currency bonds. And while the home bias against sovereign local currency bonds is substantial, it pales in comparison to that against corporate local currency bonds. Indeed, to a first approximation, EME corporates can only reach US investors if they issue USD-denominated bonds. 


\section{REFERENCES}

Ahmed, S. and A. Zlate. 2014. “Capital Flows to Emerging Market Economies: A Brave New World?" Journal of International Money and Finance 48: 221-48.

Ahmed, S., S. Curcuru, F. Warnock and A. Zlate. 2016. "Decomposing International Portfolio Flows.” Mimeographed.

Aizenman, J., M. Binici and M.M. Hutchison. 2016. "The Transmission of Federal Reserve Tapering News to Emerging Financial Markets." International Journal of Central Banking 317-56.

Bauer, M.D. 2012. "Fed Asset Buying and Private Borrowing Rates." FRBSF Economic Letter 2012-16, May 21.

Bauer, M.D. and G.D. Rudebusch. 2014. "The Signaling Channel for Federal Reserve Bond Purchases." International Journal of Central Banking 10(3): 233-89.

Bauer, M.D. and C.J. Neely. 2014. "International Channels of the Fed's Unconventional Monetary Policy.” Journal of International Money and Finance 44: 24-46.

Baumeister, C. and L. Benati. 2013. "Unconventional Monetary Policy and the Great Recession: Estimating the Macroeconomic Effects of a Spread Compression at the Zero Lower Bound." International Journal of Central Banking 9: $165-212$.

Bekaert, G. and X. Wang. 2009, "Home Bias Revisited.” Unpublished working paper.

Bhattarai, S., A. Chatterjee and W.Y. Park. 2015. "Effects of US Quantitative Easing on Emerging Market Economies." Federal Reserve Bank of Dallas Globalization and Monetary Policy Institute Working Paper No. 255.

Blank, S. and C. Buch. 2007. "The Euro and Cross-Border Banking: Evidence from Bilateral Data." Comparative Economic Studies 49: 389-410.

Bowman, D., J.M. Londono and H. Sapriza. 2015. "US Unconventional Monetary Policy and Transmission to Emerging Market Economies." Journal of International Money and Finance 55: 27-59.

Burger, J. and F. Warnock. 2003. "Diversification, Original Sin and International Bond Portfolios." International Finance Discussion Paper No.755, Board of Governors of the Federal Reserve System. 2006. "Local Currency Bond Markets." IMF Staff Papers 53: 133-46. .2007. "Foreign Participation in Local-Currency Bond Markets." Review of Financial Economics 16(3): 291-304.

Burger, J., F. Warnock and V.C. Warnock. 2012. “Emerging Local Currency Bond Markets.” Financial Analysts Journal 68(4): 73-93.

. 2017. "Currency Matters: Analyzing International Bond Portfolios.” NBER Working Paper 23175.

Burger, J., R. Sengupta, F. Warnock and V. C. Warnock. 2015. "US Investment in Global Bonds: As the Fed Pushes, Some EMEs Pull.” Economic Policy 30 (84): 729-66.

Calvo, G.A., L. Leiderman and C.M. Reinhart. (1993). "Capital Inflows and Real Exchange Rate Appreciation in Latin America: The Role of External Factors.” IMF Staff Papers 40(1): 108-51.

Chen, H., V. Curdia and A. Ferrero. 2012. "The Macroeconomic Effects of Large-Scale Asset Purchase Programmes." Economic Journal 122: 289-315.

Chuhan, P., S. Claessens and N. Mamingi. 1998. "Equity and Bond Flows to Latin America and Asia: The Role of Global and Country Factors." Journal of Development Economics 55(2): 439-63.

Claessens, S., D. Klingebiel and S. Schmukler. 2007. "Government Bonds in Domestic and Foreign Currency: The Role of Institutional and Macroeconomic Factors." Review of International Economics 15(2): 370-413.

Cooper, I. and E. Kaplanis. 1986. Costs to Crossborder Investment and International Equity Market Equilibrium.” In Recent Developments in Corporate Finance, edited by J. Edwards, J. Franks, C. Mayer and S. Schaefer. Cambridge University Press.

Dahlhaus, T. and G. Vasishtha. 2014. "The Impact of US Monetary Policy Normalization on Capital Flows to EmergingMarket Economies.” Bank of Canada Working Paper No. 2014-53.

D'Amico, S. and T.B. King. 2013. "Flow and Stock Effects of Large-Scale Treasury Purchases: Evidence on the Importance of Local Supply." Journal of Financial Economics 108: 425-48.

Eichengreen, B. and P. Luengnaruemitchai. 2006. “Why Doesn't Asia Have Bigger Bond Markets?” In BIS Papers No. 30: Asian Bond Markets: Issues and Prospects. Basel, Switzerland: Bank for International Settlements. 
Eichengreeen, B. and P. Gupta. 2015. "Tapering Talk: The Impact of Expectations of Reduced Federal Reserve Purchases on Emerging Markets." Emerging Markets Review 25: 1-15.

Fawley, Brett W. and Christopher J. Neely. 2013. "Four Stories of Quantitative Easing." Federal Reserve Bank of St. Louis Review, Jan/Feb, 51-88.

Fidora, M., M. Fratzscher and C. Thimann. 2007. "Home Bias in Global Bond and Equity Markets: The Role of Real Exchange Rate Volatility.” Journal of International Money and Finance 26: 631-55.

Fratzscher, M. 2012. "Capital Flows, Push versus Pull Factors and the Global Financial Crisis." Journal of International Economics 88(2): 341-56.

Forbes, K. and F. Warnock. 2013. "Debt- and Equity-Led Capital Flow Episodes." in Capital Mobility and Monetary Policy, edited by M. Fuentes and C.M. Reinhart. Santiago: Central Bank of Chile. Also available as NBER Working Paper No. 18329.

Gagnon, J., M. Raskin, J. Remache and B. Sack. 2010. "Large-scale Asset Purchases by the Federal Reserve: Did They Work?" Staff Reports No. 441, Federal Reserve Bank of New York.

Gambacorta, L., B. Hoffman and G. Peersman. 2014. "The Effectiveness of Unconventional Monetary Policy at the Zero Lower Bound: A Cross-Country Analysis.” Journal of Money, Credit and Banking 46: 615-42.

Glick, R. and S. Leduc. 2012. "Central Bank Announcements of Asset Purchases and the Impact on Global Financial and Commodity Markets." Journal of International Money and Finance 31: 2078-101.

. 2013. "The Effects of Unconventional and Conventional US Monetary Policy on the Dollar." San Francisco Fed Working Paper No. 2013-11.

Goldstein, M. and P. Turner. 2004. Controlling Currency Mismatches in Emerging Economies. Washington, DC: Institute for International Economics.

Gourinchas, P.-O. and M. Obstfeld. 2012. "Stories of the Twentieth Century for the Twenty-First." American Economic Journal: Macroeconomics 4(1): 226-65.

Griever, W., G. Lee and F. Warnock. 2001. "The US System for Measuring Cross-Border Investment in Securities: A Primer with a Discussion of Recent Developments." Federal Reserve Bulletin 87(10): 633-50.

Gruić, B. and P. Wooldridge. 2012. "Enhancements to the BIS Debt Securities Statistics." BIS Quarterly Review (December): 63-76.

Gurkaynak, R., B. Sack and E. Swanson. 2005. "Do Actions Speak Louder than Words? The Response of Asset Prices to Monetary Policy Actions and Statements." International Journal of Central Banking 1: 55-93.

Hale, G. and M. Obstfeld. 2016. "The Euro and the Geography of International Debt Flows." Journal of European Economic Association 14(1): 115-44.

Hamilton, J.D. and C. Wu. 2012. "The Effectiveness of Alternative Monetary Policy Tools in a Zero Lower Bound Environment." Journal of Money, Credit and Banking 44: 3-46.

Holland, S., S. Sarkissian, M. Schill and F. Warnock. 2016. "Global Equity Investment.” Mimeographed.

Krishnamurthy, A. and A. Vissing-Jorgensen. 2011. "The Effects of Quantitative Easing on Interest Rates: Channels and Implications for Policy." Brookings Papers on Economic Activity, Fall.

Lane, P. 2006. "Global Bond Portfolios and EMU.” International Journal of Central Banking 2(2): 1-23.

Leal, R.P.C. and A.L. Carvalhal da Silva. 2008. "Development of the Brazilian Bond Market." In Bond Markets in Latin America: On the Verge of a Big Bang? , edited by E. Borensztein, K. Cowan, B. Eichengreen and U. Panizza. MIT Press.

Lim, J.J., S. Mohapatra and M. Stoker. 2014. "Tinker, Taper, QE, Bye? The Effect of Quantitative Easing on Financial Flows to Developing Countries." Background paper for Global Economic Prospects 2014, Washington, DC: World Bank.

Markit Indices Limited. 2013. "GEMLOC Investability Indicator Methodology.” February 2013, https://www.markit.com/assets/en/docs/products/data/indices/bondindices/GEMLOC\%20Investability\%20Indicator\%20Methodology.pdf

McCauley, R., C. Upper and A. Villar. 2013. "Emerging Market Debt Securities Issuance in Offshore Centers.” BIS Quarterly Review (September, Box 2).

Mendoza, E. and M. Terrones. 2008. "An Anatomy of Credit Booms: Evidence from Macro Aggregates and Micro Data." NBER Working Paper No. 14049. 
Rogers, J.H., C. Scotti and J. Wright. 2014. "Evaluating Asset-Market Effects of Unconventional Monetary Policy: A MultiCountry Review." Economic Policy 749-99. . 2016. "Unconventional Monetary Policy and International Risk Premia." International Finance Discussion Papers No. 1172.

Schularick, M. and A. M. Taylor. 2012. "Credit Booms Gone Bust: Monetary Policy, Leverage Cycles and Financial Crises, 1870-2008.” American Economic Review 102: 1029-61.

Swanson, E. 2016. "Measuring the Effects of Federal Reserve Forward Guidance and Asset Purchases on Financial Markets." Mimeographed, University of California, Irvine.

Tillmann, P. 2014. "Unconventional Monetary Policy Shocks and the Spillovers to Emerging Markets." Working Paper.

US Department of the Treasury, Federal Reserve Bank of New York and Board of Governors of the Federal Reserve System. 2008. Report on Foreign Portfolio Investment in the United States as of December 31. 2007.

2016. US Portfolio Holdings of Foreign Securities as of December 31, 2015.

Wright, J. 2012. "What Does Monetary Policy Do to Long-Term Interest Rates at the Zero Lower Bound?" Economic Journal 122: F447-F466. 


\section{Figure 1. 10-year Treasury Yields and LSAPs}

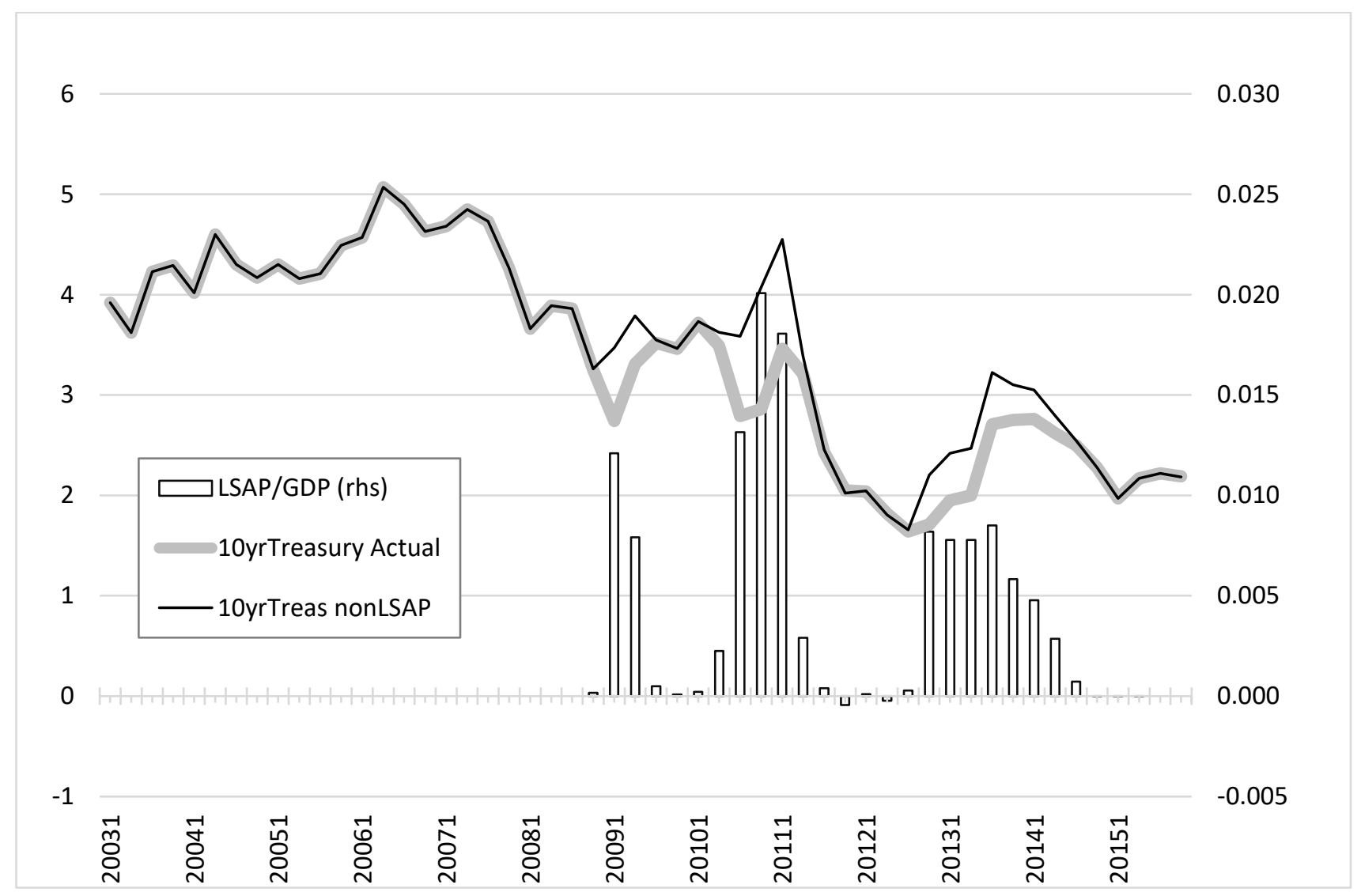

Table 1. US 10-year Treasury Yields, Decomposition and Unconventional Monetary Policy 10-year Treasury Yield

\begin{tabular}{c|ccccc}
\multicolumn{2}{c}{ Actual } & Non-LSAP & LSAP & UMP & LSAP/GDP \\
\hline \multicolumn{2}{c}{ usil0 } & usilo_nonlsap & usilo_lsap & us_ump10 & lsap_flow_gdp \\
\hline 2007 & 4.63 & 4.63 & 0.00 & 0.000 & 0.000 \\
2008 & 3.67 & 3.67 & 0.00 & -0.351 & 0.000 \\
2009 & 3.26 & 3.57 & -0.31 & -0.322 & 0.094 \\
2010 & 3.21 & 3.75 & -0.54 & -0.026 & 0.021 \\
2011 & 2.79 & 3.10 & -0.32 & -0.062 & 0.029 \\
2012 & 1.80 & 1.93 & -0.13 & 0.108 & 0.003 \\
2013 & 2.35 & 2.80 & -0.45 & -0.019 & 0.066 \\
2014 & 2.54 & 2.67 & -0.13 & 0.207 & 0.027 \\
2015 & 2.14 & 2.14 & 0.00 & -0.411 & 0.000
\end{tabular}


Table 2. EME Bond Markets

Size of EME Local Currency Bond Markets

$\begin{array}{lrr}\text { \$ billions } & 2289 & 3281 \\ \text { \% sovereign } & 52.7 & 54.1 \\ \text { \% of GDP } & 41.9 & 45.7 \\ \text { \% of global bond market } & 2.7 & 3.5 \\ \text { Size of EME USD-denominated Bond Markets } & & \\ \text { \$ billions } & 357 & 714 \\ \text { \% sovereign } & 44.1 & 31.0 \\ \text { \% of GDP } & 6.5 & 9.9 \\ \text { \% of global bond market } & 0.4 & 0.8 \\ \text { Ratio of Local Currency to Total Bonds (\%) } & 84.0 & 79.4 \\ \text { Local Currency Share of Sovereign Bonds (\%) } & 86.4 & 87.1 \\ \text { Local Currency Share of Private Bonds (\%) } & 81.5 & 71.9\end{array}$

Note: This table includes data for Chile, Colombia, Mexico, Peru; South Korea, Malaysia, Pakistan, Philippines, Thailand; and Israel, Russia, South Africa and Turkey. 
Figure 2: Currency Composition of Bond Markets

Figure 2a. Amounts in Billions of Dollars
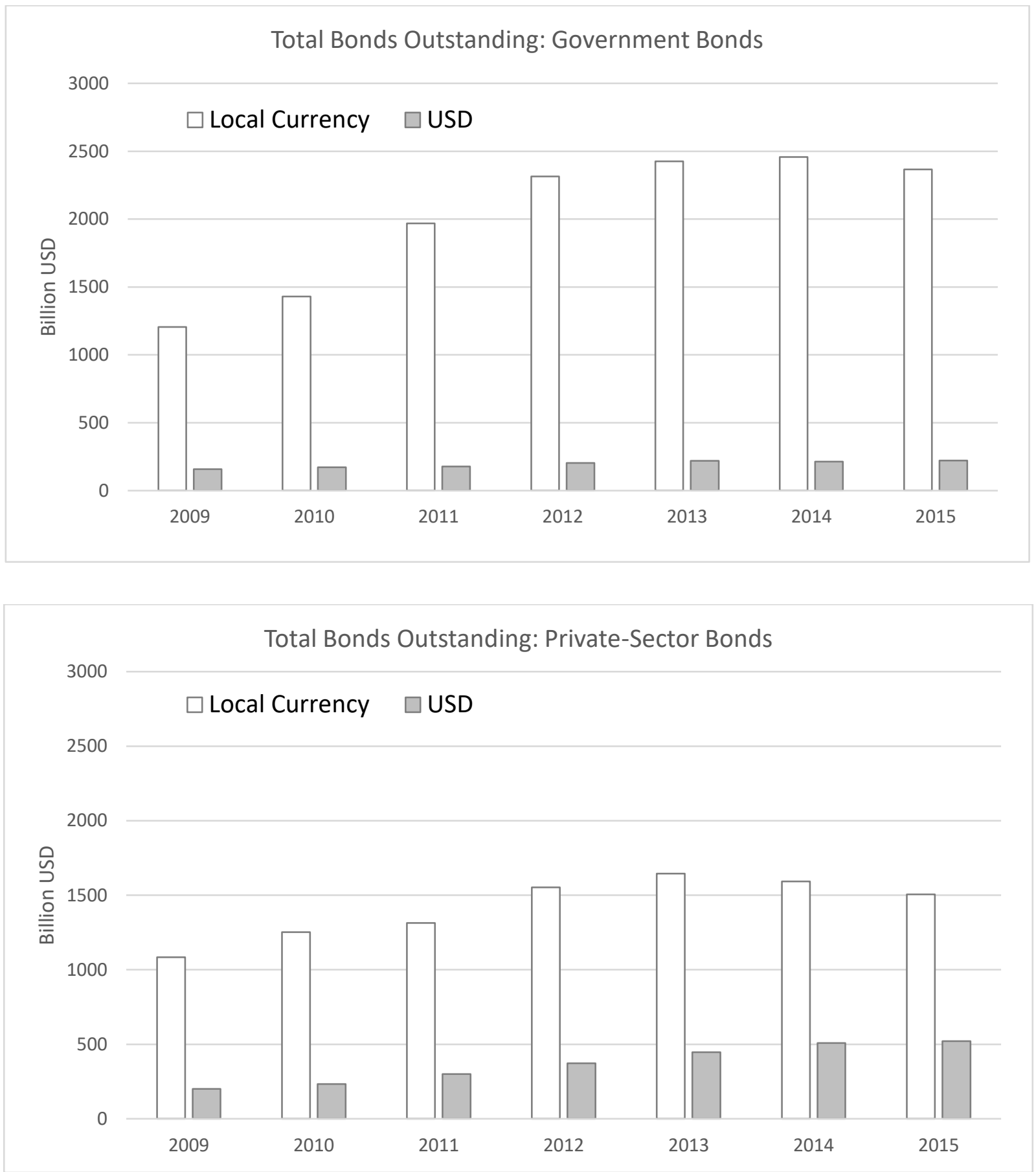
Figure 2b. As a Share of GDP: Sovereign Local Currency Bonds

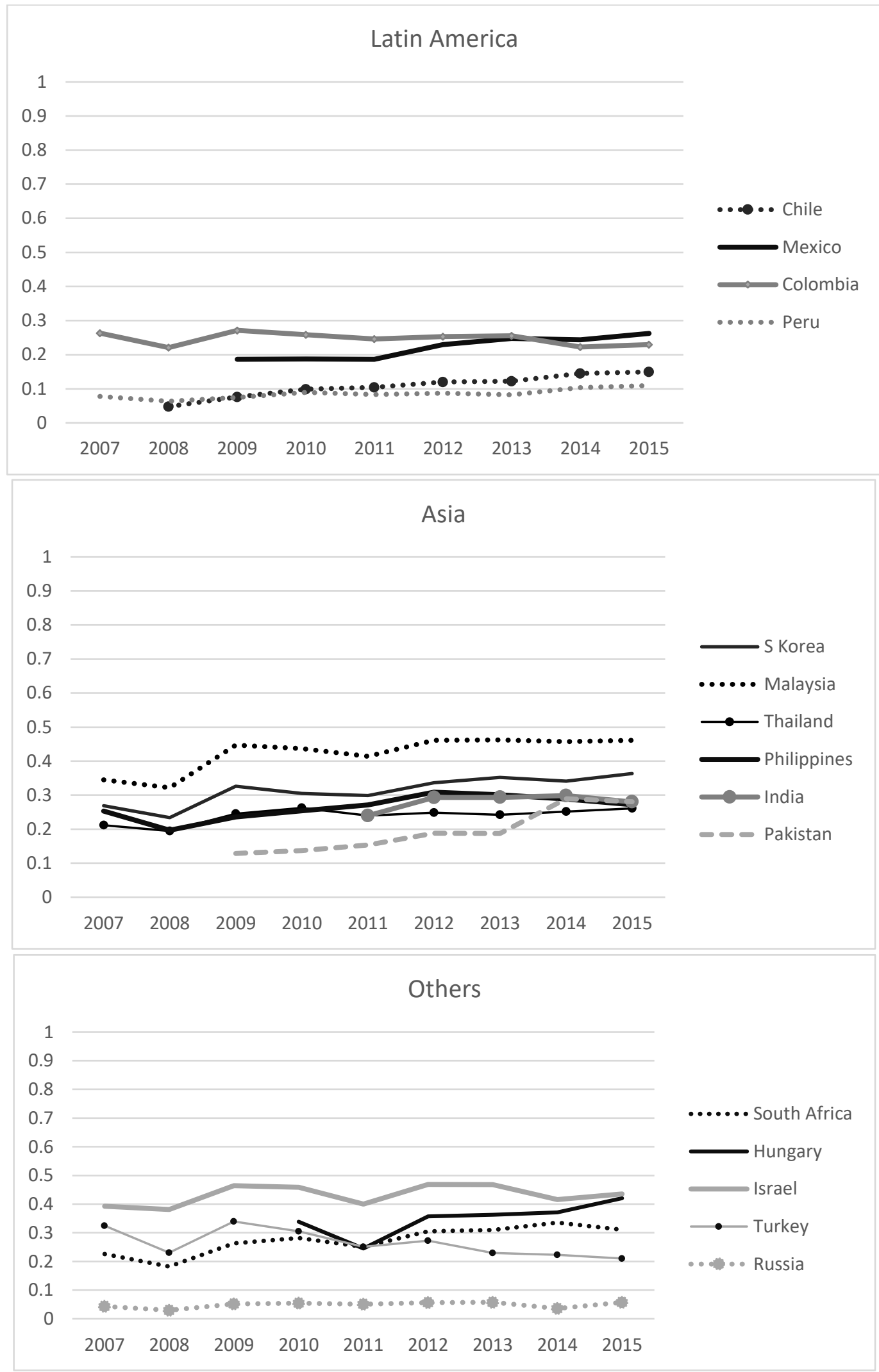


Figure 2c. As a Share of GDP: Private Sector Local Currency Bonds

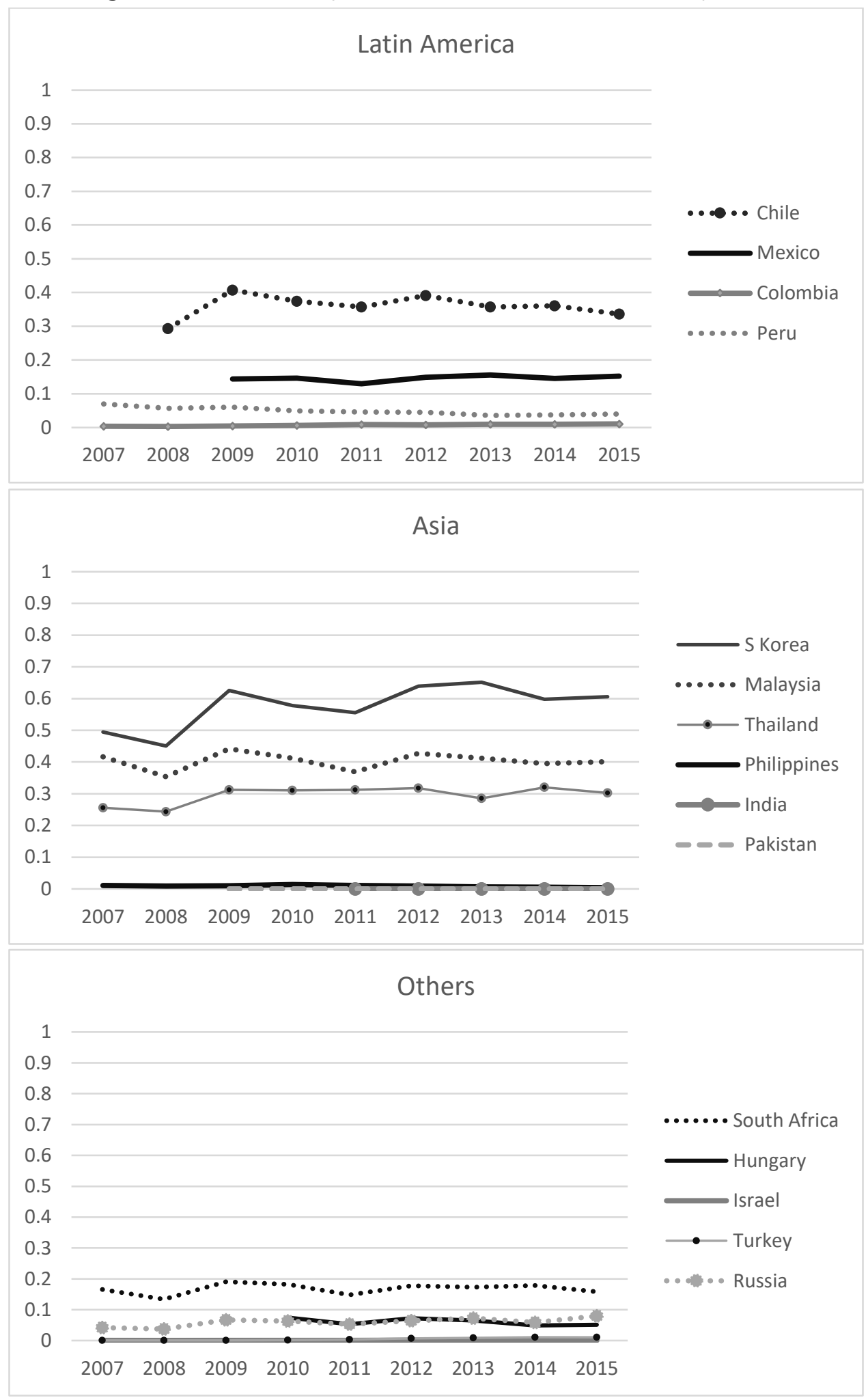


Figure 2d. As a Share of All Sovereign Bonds: Local Currency Bonds

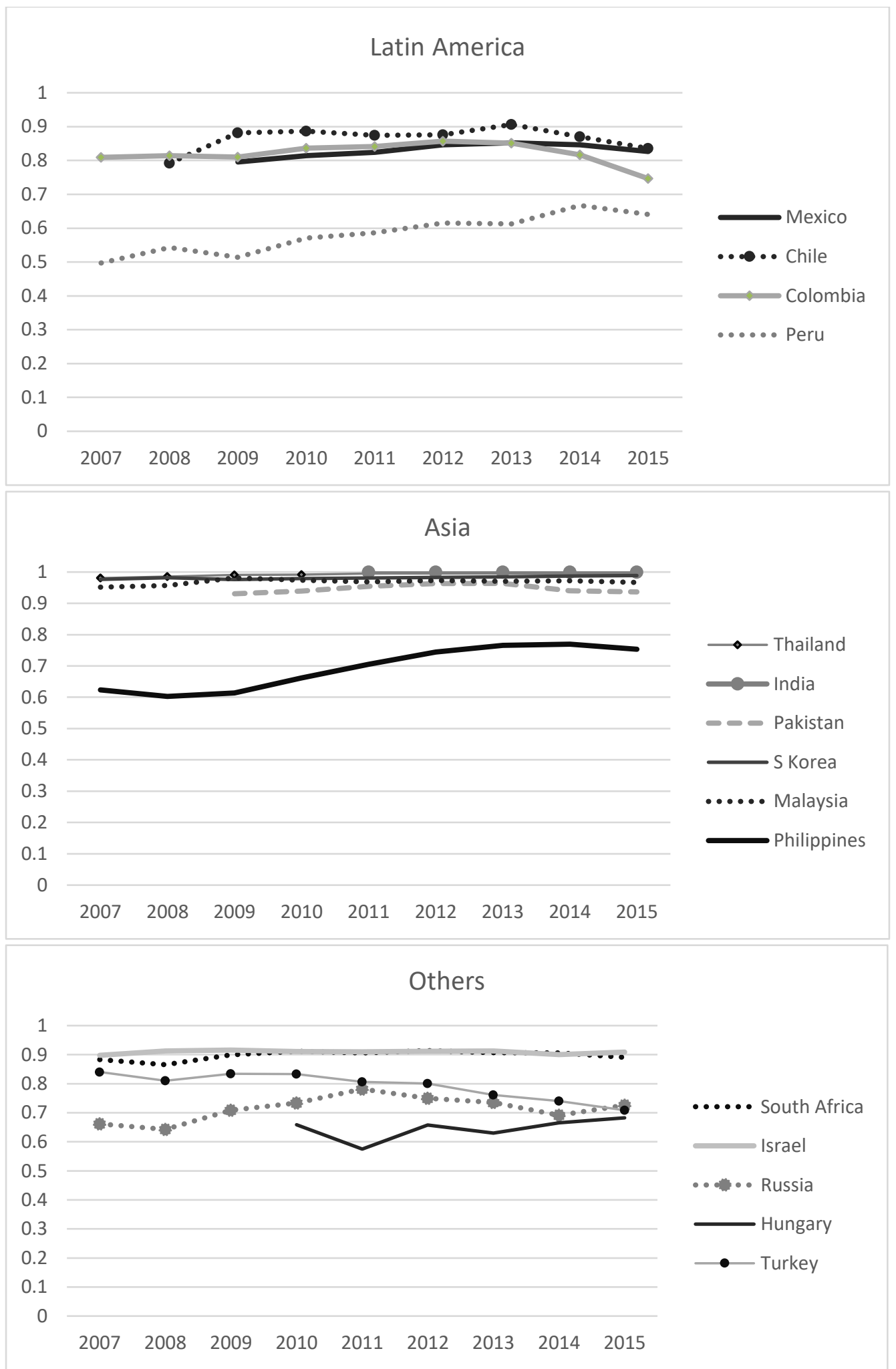


Figure 2e. As a Share of All Private Bonds: Local Currency Bonds

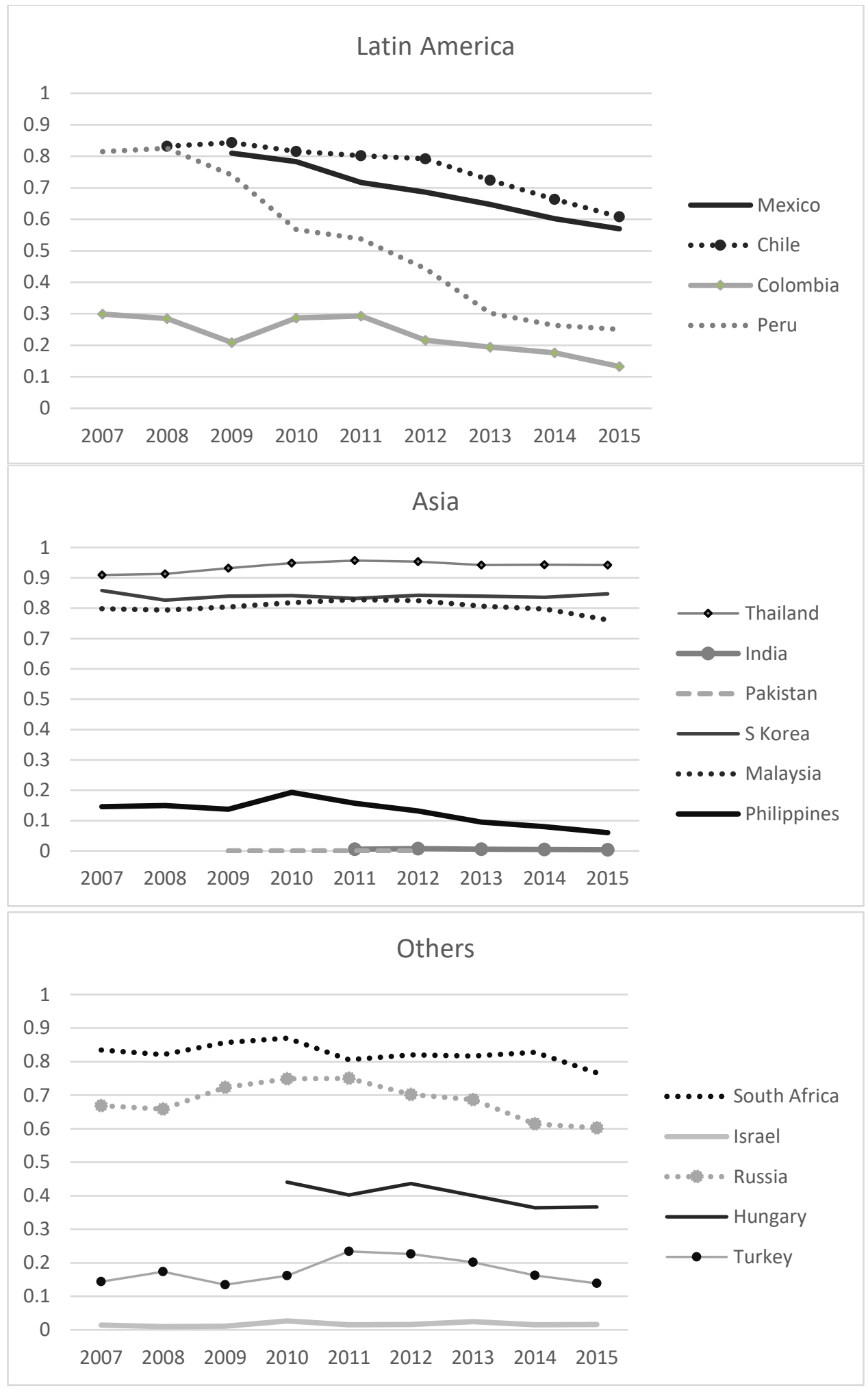




\section{Table 3. Bond Market Structure Regressions}

The annual panel data spans 2007 to 2015 and includes 15 Emerging Market Economies (EMEs). Because of data limitations, some EMEs enter the panel later than 2007. In Table 3a, time-fixed effects are included and independent variables are, in the order that they are listed, local currency bonds (all, sovereign or private) scaled by GDP; foreign currency bonds (all, sovereign or private) scaled by GDP; and the share of local currency to total bonds (all, sovereign or private). Independent variables are, in order, fiscal balance (scaled by GDP), current account balance (scaled by GDP), inflation volatility, real GDP growth, size of the local economy (calculated as the log nominal GDP in USD), our Regulatory quality/Creditor Rights variable and openness. In Panels $b$ - $d$, the time-fixed effects are replaced by global variables (the non-LSAP portion of US 10-year Treasury yields and the LSAP effect on US 10-year Treasury yields). Constants are included but not reported. Estimates are calculated using panel-feasible generalized least squares (FGLS), allowing for heteroscedastic error structures and different autocorrelation coefficients within countries. $p$-values are reported in parentheses. ${ }^{* * *},{ }^{* *}$ and $*$ denote significance levels at $1 \%, 5 \%$ and $10 \%$, respectively. Wald tests (not reported) show that the explanatory variables are always jointly significant. 
Table 3a. Bond Market Structure Regressions (with Time-Fixed Effects)

\begin{tabular}{|c|c|c|c|c|c|c|}
\hline & \multicolumn{3}{|c|}{ Sovereign } & \multicolumn{3}{|c|}{ Private } \\
\hline & $\begin{array}{c}\text { Local } \\
\text { Currency }\end{array}$ & USD & $\begin{array}{l}\text { Share of } \\
\text { Local } \\
\text { Currency }\end{array}$ & $\begin{array}{l}\text { Local } \\
\text { Currency }\end{array}$ & USD & $\begin{array}{l}\text { Share of } \\
\text { Local } \\
\text { Currency }\end{array}$ \\
\hline & LC Govt & FC Govt & LCShr Govt & LC Pvt & FC Pvt & LCShr Pvt \\
\hline fbal & $\begin{array}{l}-0.004 * \\
(0.002)\end{array}$ & $\begin{array}{c}0.001 \\
(0.000)\end{array}$ & $\begin{array}{l}-0.007^{* * *} \\
(0.002)\end{array}$ & $\begin{array}{c}0.002 \\
(0.001)\end{array}$ & $\begin{array}{c}0.000 \\
(0.001)\end{array}$ & $\begin{array}{l}0.024 * * * \\
(0.005)\end{array}$ \\
\hline$c a b$ & $\begin{array}{l}0.234 * * \\
(0.108)\end{array}$ & $\begin{array}{l}-0.000 \\
(0.024)\end{array}$ & $\begin{array}{l}0.192 * \\
(0.115)\end{array}$ & $\begin{array}{l}0.285^{* *} \\
(0.123)\end{array}$ & $\begin{array}{l}0.160 * * * \\
(0.035)\end{array}$ & $\begin{array}{l}0.518 * * \\
(0.251)\end{array}$ \\
\hline infvol & $\begin{array}{l}-0.011 * * \\
(0.005)\end{array}$ & $\begin{array}{l}-0.001 \\
(0.001)\end{array}$ & $\begin{array}{c}0.004 \\
(0.004)\end{array}$ & $\begin{array}{l}-0.003 \\
(0.003)\end{array}$ & $\begin{array}{l}-0.001 \\
(0.001)\end{array}$ & $\begin{array}{l}-0.022 * * \\
(0.010)\end{array}$ \\
\hline growth & $\begin{array}{l}0.671 * * \\
(0.299)\end{array}$ & $\begin{array}{l}-0.057 \\
(0.048)\end{array}$ & $\begin{array}{c}0.328 \\
(0.348)\end{array}$ & $\begin{array}{l}-0.122 \\
(0.195)\end{array}$ & $\begin{array}{c}0.078 \\
(0.070)\end{array}$ & $\begin{array}{l}-1.006 \\
(0.675)\end{array}$ \\
\hline nomgdp & $\begin{array}{l}-0.000 \\
(0.000)\end{array}$ & $\begin{array}{l}-0.000 * * * \\
(0.000)\end{array}$ & $\begin{array}{l}0.000 * * \\
(0.000)\end{array}$ & $\begin{array}{l}-0.000 \\
(0.000)\end{array}$ & $\begin{array}{l}-0.000 * * * \\
(0.000)\end{array}$ & $\begin{array}{l}0.000 * * * \\
(0.000)\end{array}$ \\
\hline trade_gdp & $\begin{array}{l}-2.532 * * * \\
(0.618)\end{array}$ & $\begin{array}{l}-0.834 * * \\
(0.360)\end{array}$ & $\begin{array}{c}8.130 * \\
(4.726)\end{array}$ & $\begin{array}{l}2.680 \text { ** } \\
(1.290)\end{array}$ & $\begin{array}{l}1.276 * * * \\
(0.340)\end{array}$ & $\begin{array}{l}4.213 * * \\
(1.770)\end{array}$ \\
\hline regcr & $\begin{array}{l}0.138 * * * \\
(0.038)\end{array}$ & $\begin{array}{l}-0.029 * * * \\
(0.010)\end{array}$ & $\begin{array}{l}0.123 * * \\
(0.056)\end{array}$ & $\begin{array}{c}0.077 * \\
(0.046)\end{array}$ & $\begin{array}{l}0.058^{* * *} \\
(0.014)\end{array}$ & $\begin{array}{l}0.377 * * * \\
(0.092)\end{array}$ \\
\hline caopen & $\begin{array}{c}0.042 \\
(0.038)\end{array}$ & $\begin{array}{c}0.004 \\
(0.006)\end{array}$ & $\begin{array}{l}-0.022 \\
(0.046)\end{array}$ & $\begin{array}{c}0.023 \\
(0.032)\end{array}$ & $\begin{array}{l}0.034 * * * \\
(0.009)\end{array}$ & $\begin{array}{c}0.183 * \\
(0.099)\end{array}$ \\
\hline 2008.year & $\begin{array}{l}-0.019^{*} \\
(0.010)\end{array}$ & $\begin{array}{l}-0.004 * * \\
(0.002)\end{array}$ & $\begin{array}{l}-0.003 \\
(0.010)\end{array}$ & $\begin{array}{l}-0.004 \\
(0.009)\end{array}$ & $\begin{array}{c}0.004 \\
(0.003)\end{array}$ & $\begin{array}{l}0.040 * * \\
(0.020)\end{array}$ \\
\hline 2009.year & $\begin{array}{l}0.039 * * \\
(0.016)\end{array}$ & $\begin{array}{l}-0.001 \\
(0.003)\end{array}$ & $\begin{array}{l}-0.002 \\
(0.016)\end{array}$ & $\begin{array}{c}0.027^{*} \\
(0.015)\end{array}$ & $\begin{array}{l}0.011^{* *} \\
(0.005)\end{array}$ & $\begin{array}{l}0.089 * * * \\
(0.033)\end{array}$ \\
\hline 2010.year & $\begin{array}{l}0.049 * * * \\
(0.015)\end{array}$ & $\begin{array}{c}0.000 \\
(0.003)\end{array}$ & $\begin{array}{c}0.003 \\
(0.016)\end{array}$ & $\begin{array}{c}0.016 \\
(0.015)\end{array}$ & $\begin{array}{c}0.013 * * \\
(0.006)\end{array}$ & $\begin{array}{c}0.046 \\
(0.034)\end{array}$ \\
\hline 2011.year & $\begin{array}{l}0.043 * * * \\
(0.014)\end{array}$ & $\begin{array}{l}-0.000 \\
(0.003)\end{array}$ & $\begin{array}{c}0.010 \\
(0.016)\end{array}$ & $\begin{array}{c}0.001 \\
(0.016)\end{array}$ & $\begin{array}{l}0.016^{* * *} \\
(0.005)\end{array}$ & $\begin{array}{l}-0.023 \\
(0.033)\end{array}$ \\
\hline 2012.year & $\begin{array}{l}0.060 * * * \\
(0.013)\end{array}$ & $\begin{array}{c}0.003 \\
(0.003)\end{array}$ & $\begin{array}{c}0.006 \\
(0.016)\end{array}$ & $\begin{array}{c}0.013 \\
(0.015)\end{array}$ & $\begin{array}{l}0.022 * * * \\
(0.005)\end{array}$ & $\begin{array}{l}-0.037 \\
(0.031)\end{array}$ \\
\hline 2013.year & $\begin{array}{l}0.073 * * * \\
(0.014)\end{array}$ & $\begin{array}{c}0.003 \\
(0.003)\end{array}$ & $\begin{array}{c}0.005 \\
(0.017)\end{array}$ & $\begin{array}{c}0.013 \\
(0.016)\end{array}$ & $\begin{array}{l}0.031 * * * \\
(0.005)\end{array}$ & $\begin{array}{l}-0.070 * * \\
(0.033)\end{array}$ \\
\hline 2014.year & $\begin{array}{l}0.081 \text { *** } \\
(0.015)\end{array}$ & $\begin{array}{c}0.003 \\
(0.004)\end{array}$ & $\begin{array}{c}0.005 \\
(0.018)\end{array}$ & $\begin{array}{c}0.007 \\
(0.017)\end{array}$ & $\begin{array}{l}0.037 * * * \\
(0.006)\end{array}$ & $\begin{array}{l}-0.089 * * * \\
(0.034)\end{array}$ \\
\hline 2015.year & $\begin{array}{l}0.086^{* * * *} \\
(0.015)\end{array}$ & $\begin{array}{c}0.006 \\
(0.004)\end{array}$ & $\begin{array}{l}-0.011 \\
(0.018)\end{array}$ & $\begin{array}{c}0.007 \\
(0.017)\end{array}$ & $\begin{array}{l}0.043 * * * \\
(0.006)\end{array}$ & $\begin{array}{l}-0.106^{* * * *} \\
(0.036)\end{array}$ \\
\hline$N$ & 123 & 123 & 123 & 123 & 123 & 120 \\
\hline
\end{tabular}


Table 3b. Bond Market Structure Regressions (with 10 Year Treasury Yield Decomposition)

\begin{tabular}{|c|c|c|c|c|c|c|}
\hline & \multicolumn{3}{|c|}{ Sovereign } & \multicolumn{3}{|c|}{ Private } \\
\hline & $\begin{array}{l}\text { Local } \\
\text { Currency }\end{array}$ & USD & $\begin{array}{c}\text { Share of } \\
\text { Local } \\
\text { Currency }\end{array}$ & $\begin{array}{c}\text { Local } \\
\text { Currency }\end{array}$ & USD & $\begin{array}{c}\text { Share of } \\
\text { Local } \\
\text { Currency }\end{array}$ \\
\hline Fbal & $\begin{array}{c}-0.007 * * * \\
(0.002)\end{array}$ & $\begin{array}{c}0.000 \\
(0.000)\end{array}$ & $\begin{array}{c}-0.006 * * * \\
(0.002)\end{array}$ & $\begin{array}{c}0.001 \\
(0.001)\end{array}$ & $\begin{array}{l}-0.000 \\
(0.001)\end{array}$ & $\begin{array}{c}0.014 * * * \\
(0.004)\end{array}$ \\
\hline$c a b$ & $\begin{array}{l}0.328^{* * * *} \\
(0.102)\end{array}$ & $\begin{array}{c}0.012 \\
(0.022)\end{array}$ & $\begin{array}{c}0.107 \\
(0.116)\end{array}$ & $\begin{array}{c}0.345^{* * * *} \\
(0.119)\end{array}$ & $\begin{array}{r}0.125^{* * * *} \\
(0.041)\end{array}$ & $\begin{array}{l}0.505^{* *} \\
(0.220)\end{array}$ \\
\hline infuol & $\begin{array}{c}-0.012 * * * \\
(0.004)\end{array}$ & $\begin{array}{l}-0.001 \\
(0.001)\end{array}$ & $\begin{array}{l}-0.001 \\
(0.003)\end{array}$ & $\begin{array}{l}-0.001 \\
(0.003)\end{array}$ & $\begin{array}{l}-0.001 \\
(0.002)\end{array}$ & $\begin{array}{l}-0.011 \\
(0.008)\end{array}$ \\
\hline growth & $\begin{array}{c}0.119 \\
(0.245)\end{array}$ & $\begin{array}{l}-0.070 * \\
(0.042)\end{array}$ & $\begin{array}{c}0.226 \\
(0.295)\end{array}$ & $\begin{array}{l}-0.083 \\
(0.188)\end{array}$ & $\begin{array}{l}-0.149^{*} \\
(0.081)\end{array}$ & $\begin{array}{l}-0.372 \\
(0.500)\end{array}$ \\
\hline nomgdp & $\begin{array}{l}-0.000 \\
(0.000)\end{array}$ & $\begin{array}{c}-0.000 * * * * \\
(0.000)\end{array}$ & $\begin{array}{l}0.000 * * \\
(0.000)\end{array}$ & $\begin{array}{c}-0.000 * * * * \\
(0.000)\end{array}$ & $\begin{array}{l}-0.000 \\
(0.000)\end{array}$ & $\begin{array}{c}0.000 * * * * \\
(0.000)\end{array}$ \\
\hline trade_gdp & $\begin{array}{c}-2.783 * * * \\
(0.620)\end{array}$ & $\begin{array}{l}-0.375^{*} \\
(0.214)\end{array}$ & $\begin{array}{l}6.144 * \\
(3.581)\end{array}$ & $\begin{array}{c}1.868^{*} \\
(1.082)\end{array}$ & $\begin{array}{r}1.140^{* *} \\
(0.538)\end{array}$ & $\begin{array}{c}1.431 \\
(1.969)\end{array}$ \\
\hline regcr & $\begin{array}{l}0.087 * * \\
(0.039)\end{array}$ & $\begin{array}{c}-0.030 * * * \\
(0.009)\end{array}$ & $\begin{array}{l}0.117 * * \\
(0.049)\end{array}$ & $\begin{array}{c}0.049 \\
(0.045)\end{array}$ & $\begin{array}{r}0.097 * * * \\
(0.013)\end{array}$ & $\begin{array}{c}0.423^{* * * *} \\
(0.080)\end{array}$ \\
\hline caopen & $\begin{array}{c}0.038 \\
(0.039) \\
\end{array}$ & $\begin{array}{c}0.005 \\
(0.006) \\
\end{array}$ & $\begin{array}{l}-0.024 \\
(0.046)\end{array}$ & $\begin{array}{c}0.041 \\
(0.033) \\
\end{array}$ & $\begin{array}{r}0.041^{* * * *} \\
(0.011) \\
\end{array}$ & $\begin{array}{c}0.090 \\
(0.093)\end{array}$ \\
\hline usilo_nonlsap & $\begin{array}{c}-0.017 * * * * \\
(0.004)\end{array}$ & $\begin{array}{l}-0.001 \\
(0.001)\end{array}$ & $\begin{array}{l}-0.000 \\
(0.005)\end{array}$ & $\begin{array}{c}-0.011 * * * \\
(0.004)\end{array}$ & $\begin{array}{r}-0.005 * * \\
(0.002)\end{array}$ & $\begin{array}{c}0.004 \\
(0.008)\end{array}$ \\
\hline usi10_lsap & $\begin{array}{l}-0.021 \\
(0.014)\end{array}$ & $\begin{array}{l}-0.001 \\
(0.003)\end{array}$ & $\begin{array}{l}-0.006 \\
(0.017)\end{array}$ & $\begin{array}{l}-0.021 * \\
(0.012)\end{array}$ & $\begin{array}{c}0.009 \\
(0.007)\end{array}$ & $\begin{array}{l}-0.030 \\
(0.029)\end{array}$ \\
\hline$v i x$ & $\begin{array}{c}-0.244 * * * * \\
(0.051)\end{array}$ & $\begin{array}{c}-0.026 * * * * \\
(0.009)\end{array}$ & $\begin{array}{l}-0.013 \\
(0.050)\end{array}$ & $\begin{array}{l}-0.033 \\
(0.040)\end{array}$ & $\begin{array}{r}-0.052 * * * \\
(0.019)\end{array}$ & $\begin{array}{c}0.241 * * * \\
(0.089)\end{array}$ \\
\hline _cons & $\begin{array}{l}0.297 * * * \\
(0.038)\end{array}$ & $\begin{array}{c}0.091 * * * \\
(0.011)\end{array}$ & $\begin{array}{c}0.765 * * * \\
(0.057)\end{array}$ & $\begin{array}{l}0.103^{* *} \\
(0.050)\end{array}$ & $\begin{array}{l}-0.016 \\
(0.017)\end{array}$ & $\begin{array}{c}0.202 \\
(0.124)\end{array}$ \\
\hline$N$ & 123 & 123 & 123 & 123 & 123 & 120 \\
\hline
\end{tabular}


Table 3c. Bond Market Structure Regressions (with LSAP)

\begin{tabular}{|c|c|c|c|c|c|c|}
\hline & \multicolumn{3}{|c|}{ Sovereign } & \multicolumn{3}{|c|}{ Private } \\
\hline & $\begin{array}{c}\text { Local } \\
\text { Currency }\end{array}$ & USD & $\begin{array}{l}\text { Share of } \\
\text { Local } \\
\text { Currency }\end{array}$ & $\begin{array}{c}\text { Local } \\
\text { Currency }\end{array}$ & USD & $\begin{array}{l}\text { Share of } \\
\text { Local } \\
\text { Currency }\end{array}$ \\
\hline & LC Govt & FC Govt & LCShr Govt & LC Pvt & FC Pvt & LCShr Pvt \\
\hline fbal & $\begin{array}{l}-0.006 \text { *** } \\
(0.002)\end{array}$ & $\begin{array}{c}0.000 \\
(0.000)\end{array}$ & $\begin{array}{l}-0.005 * * * \\
(0.002)\end{array}$ & $\begin{array}{c}0.001 \\
(0.001)\end{array}$ & $\begin{array}{c}0.000 \\
(0.001)\end{array}$ & $\begin{array}{l}0.013 * * * \\
(0.004)\end{array}$ \\
\hline$c a b$ & $\begin{array}{l}0.290 * * * \\
(0.104)\end{array}$ & $\begin{array}{c}0.008 \\
(0.021)\end{array}$ & $\begin{array}{c}0.081 \\
(0.105)\end{array}$ & $\begin{array}{l}0.420 * * * \\
(0.128)\end{array}$ & $\begin{array}{l}0.129 * * * \\
(0.041)\end{array}$ & $\begin{array}{l}0.480 * * \\
(0.227)\end{array}$ \\
\hline infvol & $\begin{array}{l}-0.010 * * \\
(0.004)\end{array}$ & $\begin{array}{l}-0.001 \\
(0.001)\end{array}$ & $\begin{array}{l}-0.002 \\
(0.003)\end{array}$ & $\begin{array}{c}0.001 \\
(0.003)\end{array}$ & $\begin{array}{l}-0.002 \\
(0.002)\end{array}$ & $\begin{array}{l}-0.008 \\
(0.008)\end{array}$ \\
\hline growth & $\begin{array}{c}0.115 \\
(0.217)\end{array}$ & $\begin{array}{l}-0.067 * \\
(0.039)\end{array}$ & $\begin{array}{c}0.074 \\
(0.263)\end{array}$ & $\begin{array}{c}0.025 \\
(0.185)\end{array}$ & $\begin{array}{l}-0.095 \\
(0.080)\end{array}$ & $\begin{array}{l}-0.296 \\
(0.475)\end{array}$ \\
\hline nomgdp & $\begin{array}{l}-0.000 \\
(0.000)\end{array}$ & $\begin{array}{c}-0.000 * * * \\
(0.000)\end{array}$ & $\begin{array}{c}0.000 \\
(0.000)\end{array}$ & $\begin{array}{l}-0.000 * * * \\
(0.000)\end{array}$ & $\begin{array}{l}-0.000 * \\
(0.000)\end{array}$ & $\begin{array}{l}0.000 * * * \\
(0.000)\end{array}$ \\
\hline trade_gdp & $\begin{array}{l}-2.761 * * * \\
(0.617)\end{array}$ & $\begin{array}{l}-0.394 * \\
(0.204)\end{array}$ & $\begin{array}{l}16.687 * * * \\
(4.875)\end{array}$ & $\begin{array}{l}-1.299 \\
(1.779)\end{array}$ & $\begin{array}{c}1.615^{*} \\
(0.969)\end{array}$ & $\begin{array}{c}2.169 \\
(2.183)\end{array}$ \\
\hline regcr & $\begin{array}{l}0.106^{* * * *} \\
(0.040)\end{array}$ & $\begin{array}{c}-0.032 * * * \\
(0.009)\end{array}$ & $\begin{array}{l}0.092 * * \\
(0.046)\end{array}$ & $\begin{array}{c}0.069 \\
(0.043)\end{array}$ & $\begin{array}{l}0.081 * * * \\
(0.013)\end{array}$ & $\begin{array}{l}0.475 * * * \\
(0.079)\end{array}$ \\
\hline caopen & $\begin{array}{c}0.040 \\
(0.039)\end{array}$ & $\begin{array}{c}0.004 \\
(0.006)\end{array}$ & $\begin{array}{l}-0.009 \\
(0.043)\end{array}$ & $\begin{array}{c}0.008 \\
(0.033)\end{array}$ & $\begin{array}{l}0.036^{* * * *} \\
(0.011)\end{array}$ & $\begin{array}{c}0.106 \\
(0.094)\end{array}$ \\
\hline usilo & $\begin{array}{l}-0.019 * * * \\
(0.004)\end{array}$ & $\begin{array}{l}-0.001 \\
(0.001)\end{array}$ & $\begin{array}{l}-0.000 \\
(0.005)\end{array}$ & $\begin{array}{l}-0.009 * * \\
(0.004)\end{array}$ & $\begin{array}{l}-0.006^{* * *} \\
(0.002)\end{array}$ & $\begin{array}{c}0.009 \\
(0.008)\end{array}$ \\
\hline$l s a p \_f l o w \_g d p$ & $\begin{array}{c}0.097 \\
(0.063)\end{array}$ & $\begin{array}{c}0.005 \\
(0.011)\end{array}$ & $\begin{array}{c}0.056 \\
(0.059)\end{array}$ & $\begin{array}{c}0.089 * \\
(0.053)\end{array}$ & $\begin{array}{c}0.011 \\
(0.029)\end{array}$ & $\begin{array}{c}0.080 \\
(0.133)\end{array}$ \\
\hline$v i x$ & $\begin{array}{l}-0.267 * * * \\
(0.048)\end{array}$ & $\begin{array}{c}-0.027 * * * \\
(0.008)\end{array}$ & $\begin{array}{l}-0.012 \\
(0.044)\end{array}$ & $\begin{array}{l}-0.089 * * \\
(0.042)\end{array}$ & $\begin{array}{l}-0.033 * \\
(0.019)\end{array}$ & $\begin{array}{l}0.241 * * * \\
(0.085)\end{array}$ \\
\hline$N$ & 123 & 123 & 123 & 123 & 123 & 120 \\
\hline
\end{tabular}


Table 3d. Bond Market Structure Regressions (with Unconventional Monetary Policy)

\begin{tabular}{|c|c|c|c|c|c|c|}
\hline & \multicolumn{3}{|c|}{ Sovereign } & \multicolumn{3}{|c|}{ Private Sector } \\
\hline & $\begin{array}{c}\text { Local } \\
\text { Currency }\end{array}$ & USD & $\begin{array}{l}\text { Share of } \\
\text { Local } \\
\text { Currency }\end{array}$ & $\begin{array}{c}\text { Local } \\
\text { Currency }\end{array}$ & USD & $\begin{array}{l}\text { Share of } \\
\text { Local } \\
\text { Currency }\end{array}$ \\
\hline fbal & $\begin{array}{l}-0.007 * * * \\
(0.002)\end{array}$ & $\begin{array}{c}0.000 \\
(0.000)\end{array}$ & $\begin{array}{l}-0.006^{* * *} \\
(0.002)\end{array}$ & $\begin{array}{c}0.001 \\
(0.001)\end{array}$ & $\begin{array}{c}0.000 \\
(0.001)\end{array}$ & $\begin{array}{l}0.011 * * * \\
(0.004)\end{array}$ \\
\hline$c a b$ & $\begin{array}{l}0.325^{* * * *} \\
(0.102)\end{array}$ & $\begin{array}{c}0.015 \\
(0.020)\end{array}$ & $\begin{array}{c}0.174 \\
(0.108)\end{array}$ & $\begin{array}{l}0.372 * * * \\
(0.121)\end{array}$ & $\begin{array}{l}0.140^{* * *} \\
(0.041)\end{array}$ & $\begin{array}{l}0.497 * * \\
(0.218)\end{array}$ \\
\hline infuol & $\begin{array}{l}-0.012 * * * \\
(0.004)\end{array}$ & $\begin{array}{l}-0.001 \\
(0.001)\end{array}$ & $\begin{array}{c}0.000 \\
(0.003)\end{array}$ & $\begin{array}{c}0.001 \\
(0.003)\end{array}$ & $\begin{array}{l}-0.002 \\
(0.001)\end{array}$ & $\begin{array}{l}-0.007 \\
(0.008)\end{array}$ \\
\hline growth & $\begin{array}{c}0.096 \\
(0.219)\end{array}$ & $\begin{array}{l}-0.061 * \\
(0.034)\end{array}$ & $\begin{array}{c}0.266 \\
(0.267)\end{array}$ & $\begin{array}{l}-0.067 \\
(0.183)\end{array}$ & $\begin{array}{l}-0.056 \\
(0.078)\end{array}$ & $\begin{array}{l}-0.350 \\
(0.458)\end{array}$ \\
\hline nomgdp & $\begin{array}{l}-0.000 \\
(0.000)\end{array}$ & $\begin{array}{r}-0.000 * * * \\
(0.000)\end{array}$ & $\begin{array}{c}0.000 \\
(0.000)\end{array}$ & $\begin{array}{l}-0.000 * * * \\
(0.000)\end{array}$ & $\begin{array}{l}-0.000 \\
(0.000)\end{array}$ & $\begin{array}{l}0.000 * * * \\
(0.000)\end{array}$ \\
\hline trade_gdp & $\begin{array}{l}-2.815^{* * * *} \\
(0.604)\end{array}$ & $\begin{array}{r}-0.932 * * * \\
(0.209)\end{array}$ & $\begin{array}{c}3.545 \\
(2.943)\end{array}$ & $\begin{array}{l}-1.162 \\
(2.105)\end{array}$ & $\begin{array}{l}1.121 * * * \\
(0.396)\end{array}$ & $\begin{array}{c}1.788 \\
(2.094)\end{array}$ \\
\hline regcr & $\begin{array}{l}0.085^{* *} \\
(0.039)\end{array}$ & $\begin{array}{r}-0.032 * * * \\
(0.009)\end{array}$ & $\begin{array}{l}0.142 * * * \\
(0.050)\end{array}$ & $\begin{array}{c}0.055 \\
(0.045)\end{array}$ & $\begin{array}{l}0.098^{* * * *} \\
(0.012)\end{array}$ & $\begin{array}{l}0.477 * * * \\
(0.078)\end{array}$ \\
\hline caopen & $\begin{array}{c}0.034 \\
(0.039)\end{array}$ & $\begin{array}{c}0.005 \\
(0.006)\end{array}$ & $\begin{array}{l}-0.027 \\
(0.045)\end{array}$ & $\begin{array}{c}0.032 \\
(0.034)\end{array}$ & $\begin{array}{l}0.040^{* * *} \\
(0.012)\end{array}$ & $\begin{array}{c}0.082 \\
(0.091)\end{array}$ \\
\hline usilo & $\begin{array}{l}-0.016^{* * * *} \\
(0.004)\end{array}$ & $\begin{array}{l}-0.001 \\
(0.001)\end{array}$ & $\begin{array}{c}0.001 \\
(0.005)\end{array}$ & $\begin{array}{l}-0.010 * * * \\
(0.004)\end{array}$ & $\begin{array}{l}-0.005^{* * *} \\
(0.002)\end{array}$ & $\begin{array}{c}0.007 \\
(0.008)\end{array}$ \\
\hline ump_ilo & $\begin{array}{l}-0.011 \\
(0.011)\end{array}$ & $\begin{array}{l}-0.003 \\
(0.002)\end{array}$ & $\begin{array}{l}0.024 * * \\
(0.011)\end{array}$ & $\begin{array}{c}0.003 \\
(0.008)\end{array}$ & $\begin{array}{l}-0.021 * * * \\
(0.005)\end{array}$ & $\begin{array}{c}0.035 \\
(0.022)\end{array}$ \\
\hline$v i x$ & $\begin{array}{l}-0.280 * * * \\
(0.052)\end{array}$ & $\begin{array}{r}-0.033^{* * *} \\
(0.009)\end{array}$ & $\begin{array}{c}0.046 \\
(0.055)\end{array}$ & $\begin{array}{l}-0.045 \\
(0.043)\end{array}$ & $\begin{array}{l}-0.084 * * * \\
(0.021)\end{array}$ & $\begin{array}{l}0.313^{\text {*** }} \\
(0.102)\end{array}$ \\
\hline$N$ & 123 & 123 & 123 & 123 & 123 & 120 \\
\hline
\end{tabular}


Table 4. US Portfolios of EME Bonds

$2009 \quad 2015$

Size of EME Local Currency Bond Markets

$\$$ billions

$2289 \quad 3281$

$\%$ sovereign

$52.7 \quad 54.1$

$\%$ of GDP

$41.9 \quad 45.7$

$\%$ of global bond market

$2.7 \quad 3.5$

Size of EME USD-denominated Bond Markets

$\$$ billions

$357 \quad 714$

$\%$ sovereign

$44.1 \quad 31.0$

$\%$ of GDP

$6.5 \quad 9.9$

$\%$ of global bond market

$0.4 \quad 0.8$

$\begin{array}{lll}\text { Ratio of Local Currency to Total Bonds (\%) } & 84.0 \quad 79.4\end{array}$

Local Currency Share of Sovereign Bonds (\%) $\quad 86.4 \quad 87.1$

Local Currency Share of Private Bonds (\%) $\quad 81.5 \quad 71.9$

US Holdings of EME Local Currency Bonds

$\begin{array}{lrr}\text { \$ billions } & 20 & 72 \\ \text { \% of outstanding EME Local Currency bonds } & 0.87 & 2.20 \\ \text { \% of US bond portfolio } & 0.08 & 0.24 \\ \text { RelWgt } & 0.029 & 0.07\end{array}$

US Holdings of EME USD-denominated Bonds

$\begin{array}{lrr}\text { \$ billions } & 73 & 152 \\ \text { \% of outstanding EME USD bonds } & 20.5 & 21.3 \\ \text { \% of US bond portfolio } & 0.29 & 0.51 \\ \text { RelWgt } & 0.684 & 0.674\end{array}$

Notes. For ease of comparison, the top half of this table is identical to Table 2. This table, and the below Figure 3, includes data for Chile, Colombia, Mexico, Peru; South Korea, Malaysia, Pakistan, Philippines, Thailand; and Israel, Russia, South Africa and Turkey. 
Figure 3. US Investors' Portfolio in EME Bonds
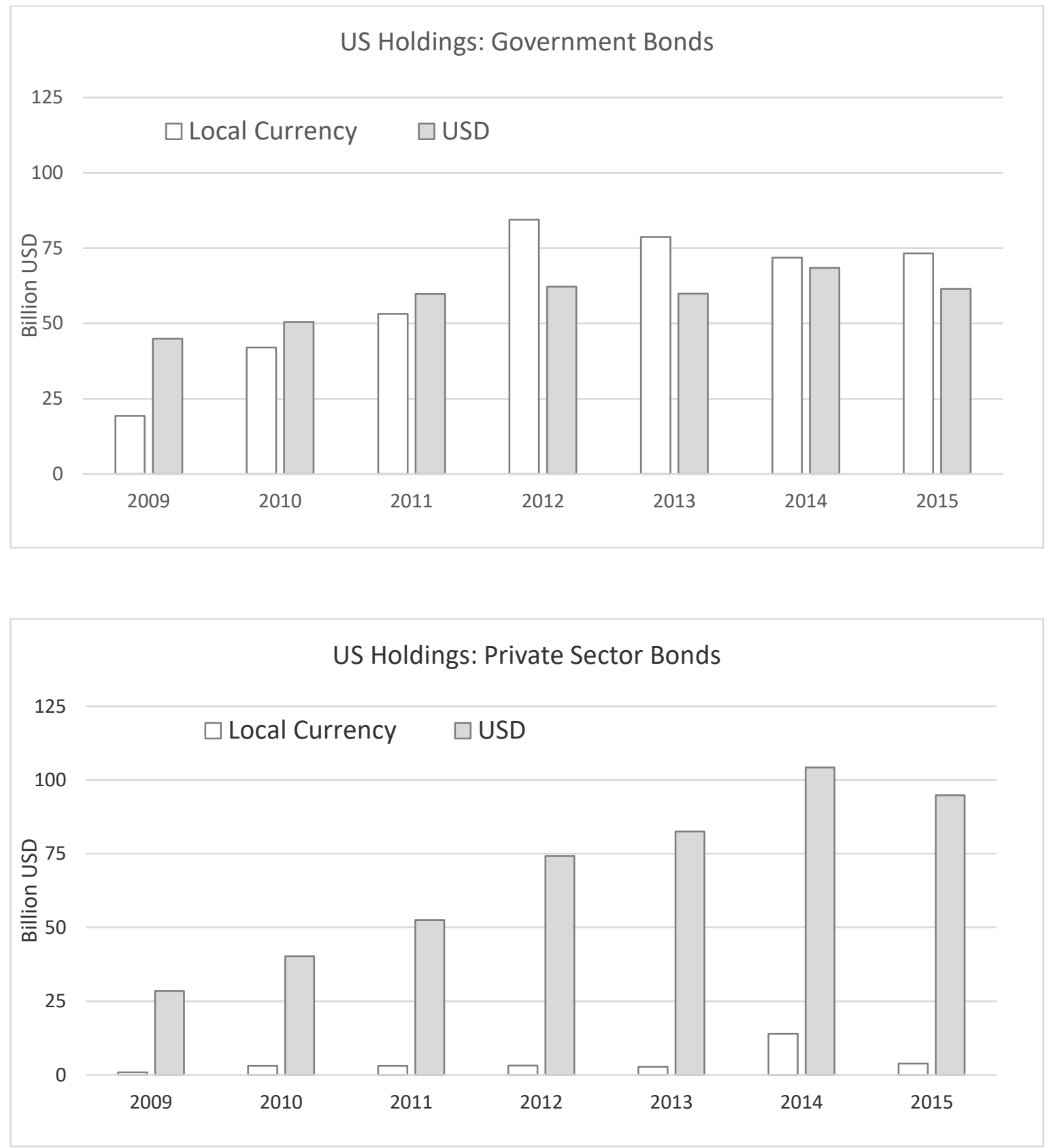
Figure 4. US Investors' Relative Weights

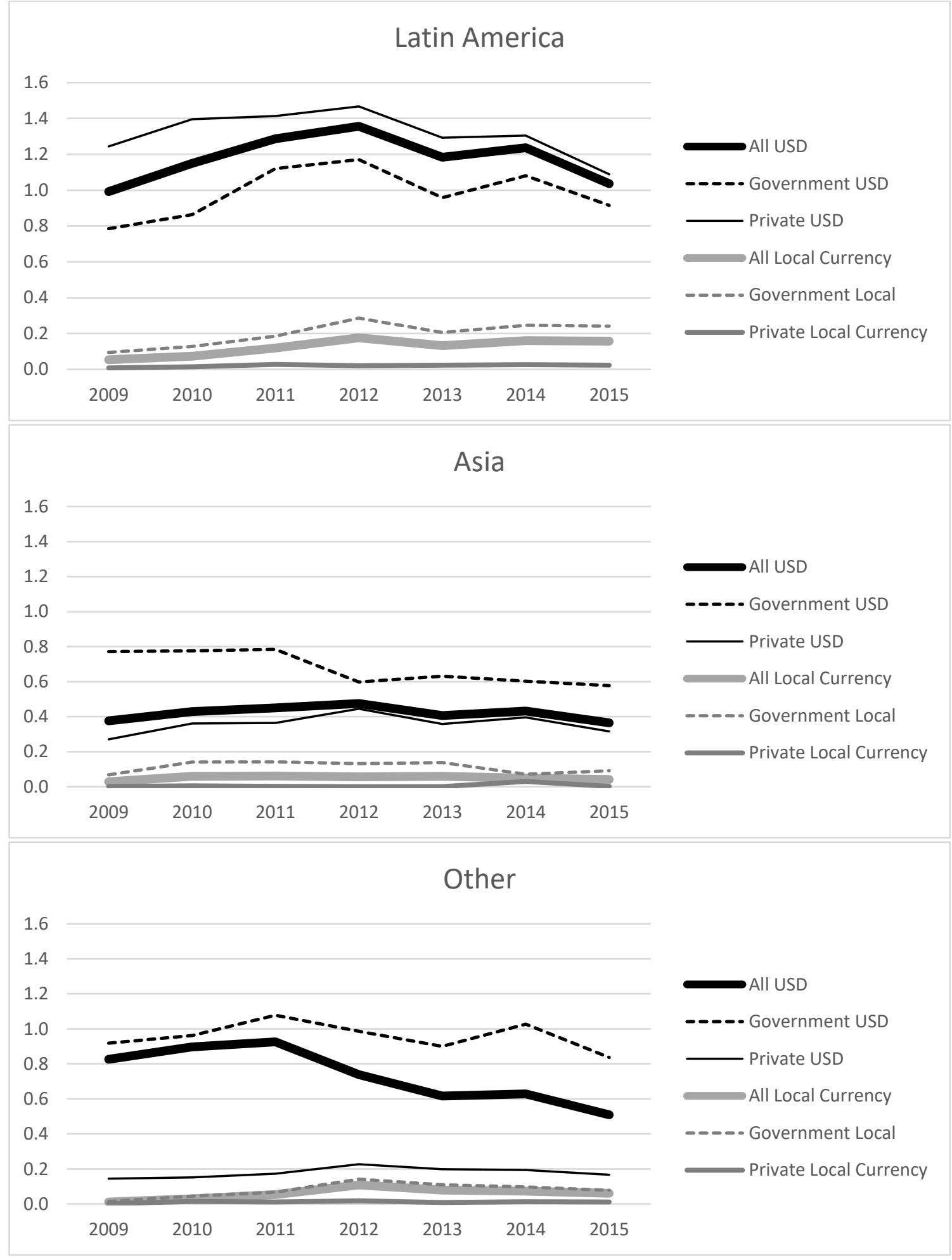




\section{Table 5. Determinants of US Investment in Local Currency Bonds}

This note is for Tables 5 and 6. In both, sovereign bonds are in Panel a and private-sector bonds are in Panel b. Annual panels span the period 2007 to 2015 and includes 15 EMEs. Because of data limitations, some EMEs enter the panel later than 2007. Dependent variables are normalized relative weights for local currency bonds in Table 5 and USD-denominated bonds in Table 6. Constants are included but not reported. Estimates are calculated using panel-feasible generalized least squares (FGLS), allowing for heteroscedastic error structures and different autocorrelation coefficients within countries. Standard errors are reported in parentheses. ***, ** and * denote significance at the $1 \%, 5 \%$ and $10 \%$ levels, respectively. 
Table 5a. Determinants of US Investment: Sovereign Local Currency Bonds

\begin{tabular}{|c|c|c|c|c|}
\hline & (1) & (2) & (3) & (4) \\
\hline fbal & $\begin{array}{l}0.002 * * * \\
(0.001)\end{array}$ & $\begin{array}{l}0.003 * * * \\
(0.001)\end{array}$ & $\begin{array}{l}0.003^{* * * *} \\
(0.001)\end{array}$ & $\begin{array}{c}0.001 \\
(0.001)\end{array}$ \\
\hline$c a b$ & $\begin{array}{c}0.065 \\
(0.050)\end{array}$ & $\begin{array}{c}0.022 \\
(0.055)\end{array}$ & $\begin{array}{c}0.004 \\
(0.056)\end{array}$ & $\begin{array}{c}0.111^{*} \\
(0.057)\end{array}$ \\
\hline infivol & $\begin{array}{l}0.004 * \\
(0.002)\end{array}$ & $\begin{array}{l}0.005^{* * * *} \\
(0.002)\end{array}$ & $\begin{array}{l}0.004 * * \\
(0.002)\end{array}$ & $\begin{array}{l}0.005^{* *} \\
(0.002)\end{array}$ \\
\hline yield & $\begin{array}{l}0.174^{*} \\
(0.091)\end{array}$ & $\begin{array}{l}0.185^{* * *} \\
(0.093)\end{array}$ & $\begin{array}{l}0.194 * * \\
(0.095)\end{array}$ & $\begin{array}{l}0.204 * * \\
(0.102)\end{array}$ \\
\hline growth & $\begin{array}{l}-0.042 \\
(0.107)\end{array}$ & $\begin{array}{l}-0.052 \\
(0.115)\end{array}$ & $\begin{array}{l}-0.033 \\
(0.121)\end{array}$ & $\begin{array}{c}0.241 * \\
(0.144)\end{array}$ \\
\hline nomgdp & $\begin{array}{l}-0.000 * * * \\
(0.000)\end{array}$ & $\begin{array}{l}-0.000 * * * \\
(0.000)\end{array}$ & $\begin{array}{l}-0.000 * * * \\
(0.000)\end{array}$ & $\begin{array}{l}-0.000 * * * \\
(0.000)\end{array}$ \\
\hline trade_gdp & $\begin{array}{l}2.828 * * * \\
(0.576)\end{array}$ & $\begin{array}{l}2.973 * * * \\
(0.457)\end{array}$ & $\begin{array}{l}2.957 * * * \\
(0.478)\end{array}$ & $\begin{array}{l}2.944 * * * \\
(0.495)\end{array}$ \\
\hline regcr & $\begin{array}{l}0.042^{* *} \\
(0.021)\end{array}$ & $\begin{array}{l}0.047 * * \\
(0.021)\end{array}$ & $\begin{array}{l}0.044 * * \\
(0.021)\end{array}$ & $\begin{array}{l}0.060^{* * * *} \\
(0.023)\end{array}$ \\
\hline caopen & $\begin{array}{c}0.015 \\
(0.014)\end{array}$ & $\begin{array}{c}0.012 \\
(0.015)\end{array}$ & $\begin{array}{c}0.007 \\
(0.015)\end{array}$ & $\begin{array}{c}0.019 \\
(0.016)\end{array}$ \\
\hline usilo & $\begin{array}{l}-0.013 * * * \\
(0.003)\end{array}$ & $\begin{array}{l}-0.011 * * * \\
(0.003)\end{array}$ & & \\
\hline ump_ilo & $\begin{array}{c}0.012 * \\
(0.006)\end{array}$ & & & \\
\hline vix & $\begin{array}{l}-0.077 * * * \\
(0.028)\end{array}$ & $\begin{array}{l}-0.106^{* * * *} \\
(0.025)\end{array}$ & $\begin{array}{l}-0.088 * * * \\
(0.024)\end{array}$ & \\
\hline$l s a p \_f l o w \_g d p$ & & $\begin{array}{c}0.026 \\
(0.033)\end{array}$ & & \\
\hline usi10_nonlsap & & & $\begin{array}{l}-0.012 * * * \\
(0.003)\end{array}$ & \\
\hline usi10_lsap & & & $\begin{array}{l}-0.026 * * * \\
(0.008)\end{array}$ & \\
\hline 2008.year & & & & $\begin{array}{c}0.001 \\
(0.005)\end{array}$ \\
\hline 2009.year & & & & $\begin{array}{c}0.010 \\
(0.009)\end{array}$ \\
\hline 2010.year & & & & $\begin{array}{l}0.029 * * * \\
(0.009)\end{array}$ \\
\hline 2011.year & & & & $\begin{array}{l}0.038 * * * \\
(0.009)\end{array}$ \\
\hline 2012.year & & & & $\begin{array}{l}0.047 * * * \\
(0.009)\end{array}$ \\
\hline 2013.year & & & & $\begin{array}{l}0.048^{* * * *} \\
(0.009)\end{array}$ \\
\hline 2014.year & & & & $\begin{array}{l}0.049 * * * \\
(0.009)\end{array}$ \\
\hline 2015.year & & & & $\begin{array}{l}0.044 * * * \\
(0.010)\end{array}$ \\
\hline$N$ & 123 & 123 & 123 & 123 \\
\hline
\end{tabular}


Table 5b. Determinants of US Investment: Private Local Currency Bonds

\begin{tabular}{|c|c|c|c|c|}
\hline & (1) & (2) & (3) & (4) \\
\hline fbal & $\begin{array}{c}-0.016^{*} \\
(0.009)\end{array}$ & $\begin{array}{r}-0.024 * * \\
(0.011)\end{array}$ & $\begin{array}{c}-0.018^{*} \\
(0.010)\end{array}$ & $\begin{array}{r}-0.030 * * \\
(0.012)\end{array}$ \\
\hline$c a b$ & $\begin{array}{l}-0.062 \\
(0.524)\end{array}$ & $\begin{array}{l}-0.188 \\
(0.590)\end{array}$ & $\begin{array}{l}-0.271 \\
(0.569)\end{array}$ & $\begin{array}{l}-0.139 \\
(0.599)\end{array}$ \\
\hline infivol & $\begin{array}{l}-0.002 \\
(0.020)\end{array}$ & $\begin{array}{l}-0.014 \\
(0.022)\end{array}$ & $\begin{array}{c}0.004 \\
(0.023)\end{array}$ & $\begin{array}{l}-0.012 \\
(0.024)\end{array}$ \\
\hline yield & $\begin{array}{c}0.113 \\
(1.034)\end{array}$ & $\begin{array}{l}-0.600 \\
(1.120)\end{array}$ & $\begin{array}{l}-0.346 \\
(1.100)\end{array}$ & $\begin{array}{l}-0.852 \\
(1.050)\end{array}$ \\
\hline growth & $\begin{array}{c}1.551 \\
(0.971)\end{array}$ & $\begin{array}{c}1.476 \\
(1.027)\end{array}$ & $\begin{array}{c}1.356 \\
(1.129)\end{array}$ & $\begin{array}{c}1.833 \\
(1.309)\end{array}$ \\
\hline nomgdp & $\begin{array}{c}0.000 \\
(0.000)\end{array}$ & $\begin{array}{c}0.000 \\
(0.000)\end{array}$ & $\begin{array}{c}0.000 \\
(0.000)\end{array}$ & $\begin{array}{c}0.000 \\
(0.000)\end{array}$ \\
\hline trade_gdp & $\begin{array}{l}-2.987 \\
(3.022)\end{array}$ & $\begin{array}{l}-4.065 \\
(2.608)\end{array}$ & $\begin{array}{l}-3.473 \\
(3.163)\end{array}$ & $\begin{array}{l}-4.473 \\
(2.884)\end{array}$ \\
\hline regcr & $\begin{array}{c}0.225 \\
(0.204)\end{array}$ & $\begin{array}{c}0.161 \\
(0.200)\end{array}$ & $\begin{array}{c}0.264 \\
(0.212)\end{array}$ & $\begin{array}{c}0.185 \\
(0.195)\end{array}$ \\
\hline caopen & $\begin{array}{r}-0.248^{*} \\
(0.141)\end{array}$ & $\begin{array}{l}-0.219 \\
(0.146)\end{array}$ & $\begin{array}{r}-0.287^{*} \\
(0.156)\end{array}$ & $\begin{array}{l}-0.210 \\
(0.147) \\
\end{array}$ \\
\hline usilo & $\begin{array}{c}0.035 \\
(0.022)\end{array}$ & $\begin{array}{c}0.043^{*} \\
(0.024)\end{array}$ & & \\
\hline ump_ilo & $\begin{array}{l}-0.019 \\
(0.053)\end{array}$ & & & \\
\hline vix & $\begin{array}{l}-0.184 \\
(0.263)\end{array}$ & $\begin{array}{c}0.013 \\
(0.256)\end{array}$ & $\begin{array}{l}-0.194 \\
(0.256)\end{array}$ & \\
\hline$l s a p \_f l o w \_g d p$ & & $\begin{array}{l}-0.644 \\
(0.407)\end{array}$ & & \\
\hline usi10_nonlsap & & & $\begin{array}{c}0.039 \\
(0.024)\end{array}$ & \\
\hline usi10_lsap & & & $\begin{array}{c}0.096 \\
(0.084)\end{array}$ & \\
\hline 2008.year & & & & $\begin{array}{l}-0.032 \\
(0.053)\end{array}$ \\
\hline 2009.year & & & & $\begin{array}{l}-0.139^{*} \\
(0.076)\end{array}$ \\
\hline 2010.year & & & & $\begin{array}{l}-0.079 \\
(0.076)\end{array}$ \\
\hline 2011.year & & & & $\begin{array}{l}-0.063 \\
(0.068)\end{array}$ \\
\hline 2012.year & & & & $\begin{array}{l}-0.130^{*} \\
(0.069)\end{array}$ \\
\hline 2013.year & & & & $\begin{array}{l}-0.135^{*} \\
(0.072)\end{array}$ \\
\hline 2014.year & & & & $\begin{array}{l}-0.103 \\
(0.070)\end{array}$ \\
\hline 2015.year & & & & $\begin{array}{l}-0.099 \\
(0.072)\end{array}$ \\
\hline$N$ & 116 & 116 & 116 & 116 \\
\hline
\end{tabular}


Table 6. Determinants of US Investment in USD-denominated Bonds

Table 6a. Determinants of US Investment: Sovereign USD-denominated Bonds

\begin{tabular}{|c|c|c|c|c|}
\hline & (1) & (2) & (3) & (4) \\
\hline fbal & $\begin{array}{c}0.006 * \\
(0.004)\end{array}$ & $\begin{array}{l}0.010^{* *} \\
(0.004)\end{array}$ & $\begin{array}{c}0.006 \\
(0.004)\end{array}$ & $\begin{array}{l}0.012 * * \\
(0.005)\end{array}$ \\
\hline$c a b$ & $\begin{array}{l}0.444 * * \\
(0.224)\end{array}$ & $\begin{array}{l}0.512 * * \\
(0.259)\end{array}$ & $\begin{array}{c}0.425^{*} \\
(0.258)\end{array}$ & $\begin{array}{l}0.567 * * \\
(0.287)\end{array}$ \\
\hline infvol & $\begin{array}{l}-0.015^{*} \\
(0.008)\end{array}$ & $\begin{array}{l}-0.018 * * \\
(0.008)\end{array}$ & $\begin{array}{l}-0.018 * * \\
(0.009)\end{array}$ & $\begin{array}{l}-0.009 \\
(0.009)\end{array}$ \\
\hline yield & $\begin{array}{l}-0.744 * * \\
(0.315)\end{array}$ & $\begin{array}{l}-0.663^{*} \\
(0.398)\end{array}$ & $\begin{array}{l}-0.906^{* *} \\
(0.393)\end{array}$ & $\begin{array}{l}-0.249 \\
(0.455)\end{array}$ \\
\hline growth & $\begin{array}{l}-0.672^{*} \\
(0.383)\end{array}$ & $\begin{array}{l}-0.843^{*} \\
(0.451)\end{array}$ & $\begin{array}{l}-0.869^{*} \\
(0.458)\end{array}$ & $\begin{array}{l}-0.142 \\
(0.560)\end{array}$ \\
\hline nomgdp & $\begin{array}{l}-0.000 * * \\
(0.000)\end{array}$ & $\begin{array}{l}-0.000 * * \\
(0.000)\end{array}$ & $\begin{array}{l}-0.000 * \\
(0.000)\end{array}$ & $\begin{array}{l}-0.000 * * * \\
(0.000)\end{array}$ \\
\hline trade_gdp & $\begin{array}{c}0.130 \\
(1.275)\end{array}$ & $\begin{array}{c}0.330 \\
(1.392)\end{array}$ & $\begin{array}{l}-0.074 \\
(1.429)\end{array}$ & $\begin{array}{c}0.881 \\
(1.353)\end{array}$ \\
\hline regcr & $\begin{array}{l}0.243 * * * \\
(0.087)\end{array}$ & $\begin{array}{l}0.226^{* *} \\
(0.091)\end{array}$ & $\begin{array}{l}0.215^{* *} \\
(0.093)\end{array}$ & $\begin{array}{l}0.317 * * * \\
(0.092)\end{array}$ \\
\hline caopen & $\begin{array}{c}0.124 * \\
(0.074)\end{array}$ & $\begin{array}{c}0.038 \\
(0.083) \\
\end{array}$ & $\begin{array}{c}0.056 \\
(0.084) \\
\end{array}$ & $\begin{array}{c}0.001 \\
(0.069) \\
\end{array}$ \\
\hline usilo & $\begin{array}{l}-0.026 * * * \\
(0.009)\end{array}$ & $\begin{array}{l}-0.029 * * * \\
(0.011)\end{array}$ & & \\
\hline ump_i10 & $\begin{array}{l}0.088 * * * \\
(0.022)\end{array}$ & & & \\
\hline$v i x$ & $\begin{array}{c}0.054 \\
(0.101)\end{array}$ & $\begin{array}{l}-0.217 * * \\
(0.106)\end{array}$ & $\begin{array}{l}-0.180 * \\
(0.100)\end{array}$ & \\
\hline$l s a p \_f l o w \_g d p$ & & $\begin{array}{c}0.157 \\
(0.159)\end{array}$ & & \\
\hline usi10_nonlsap & & & $\begin{array}{l}-0.019 * \\
(0.011)\end{array}$ & \\
\hline usi10_lsap & & & $\begin{array}{c}0.001 \\
(0.035)\end{array}$ & \\
\hline 2008.year & & & & $\begin{array}{l}-0.038^{*} \\
(0.023)\end{array}$ \\
\hline 2009.year & & & & $\begin{array}{l}0.072 * * \\
(0.036)\end{array}$ \\
\hline 2010.year & & & & $\begin{array}{l}0.084 * * \\
(0.036)\end{array}$ \\
\hline 2011.year & & & & $\begin{array}{l}0.121 * * * \\
(0.034)\end{array}$ \\
\hline 2012.year & & & & $\begin{array}{l}0.136 * * * \\
(0.033)\end{array}$ \\
\hline 2013.year & & & & $\begin{array}{l}0.100 * * * \\
(0.036)\end{array}$ \\
\hline 2014.year & & & & $\begin{array}{l}0.126 * * * \\
(0.036)\end{array}$ \\
\hline 2015.year & & & & $\begin{array}{l}0.086 * * \\
(0.038)\end{array}$ \\
\hline$N$ & 111 & 111 & 111 & 111 \\
\hline
\end{tabular}


Table $6 \mathrm{~b}$. Determinants of US Investment: Private USD-denominated Bonds

\begin{tabular}{|c|c|c|c|c|}
\hline & (1) & (2) & (3) & (4) \\
\hline fbal & $\begin{array}{l}-0.001 \\
(0.005)\end{array}$ & $\begin{array}{l}-0.000 \\
(0.006)\end{array}$ & $\begin{array}{l}-0.001 \\
(0.006)\end{array}$ & $\begin{array}{l}-0.003 \\
(0.006)\end{array}$ \\
\hline$c a b$ & $\begin{array}{l}-0.407 \\
(0.333)\end{array}$ & $\begin{array}{l}-0.464 \\
(0.321)\end{array}$ & $\begin{array}{l}-0.496 \\
(0.344)\end{array}$ & $\begin{array}{l}-0.692 * * \\
(0.320)\end{array}$ \\
\hline infuol & $\begin{array}{c}0.007 \\
(0.012)\end{array}$ & $\begin{array}{c}0.007 \\
(0.013)\end{array}$ & $\begin{array}{c}0.009 \\
(0.013)\end{array}$ & $\begin{array}{c}0.009 \\
(0.015)\end{array}$ \\
\hline yield & $\begin{array}{c}1.092 \\
(0.724)\end{array}$ & $\begin{array}{l}1.085 \\
(0.764)\end{array}$ & $\begin{array}{c}0.983 \\
(0.746)\end{array}$ & $\begin{array}{c}0.752 \\
(0.796)\end{array}$ \\
\hline growth & $\begin{array}{l}-0.601 \\
(0.679)\end{array}$ & $\begin{array}{l}-0.952 \\
(0.728)\end{array}$ & $\begin{array}{l}-0.899 \\
(0.769)\end{array}$ & $\begin{array}{l}-1.211 \\
(0.768)\end{array}$ \\
\hline nomgdp & $\begin{array}{l}-0.000 * * * \\
(0.000)\end{array}$ & $\begin{array}{l}-0.000 * * \\
(0.000)\end{array}$ & $\begin{array}{l}-0.000 * * \\
(0.000)\end{array}$ & $\begin{array}{l}-0.000 * * \\
(0.000)\end{array}$ \\
\hline trade_gdp & $\begin{array}{l}17.136 * * * \\
(1.870)\end{array}$ & $\begin{array}{l}17.521 * * * \\
(2.221)\end{array}$ & $\begin{array}{l}17.469 * * * \\
(1.978)\end{array}$ & $\begin{array}{l}16.530 * * * \\
(1.848)\end{array}$ \\
\hline regcr & $\begin{array}{c}0.178 \\
(0.128)\end{array}$ & $\begin{array}{c}0.172 \\
(0.121)\end{array}$ & $\begin{array}{c}0.131 \\
(0.127)\end{array}$ & $\begin{array}{c}0.195 \\
(0.129)\end{array}$ \\
\hline caopen & $\begin{array}{c}0.009 \\
(0.093)\end{array}$ & $\begin{array}{c}0.031 \\
(0.095)\end{array}$ & $\begin{array}{c}0.017 \\
(0.099)\end{array}$ & $\begin{array}{l}-0.000 \\
(0.093)\end{array}$ \\
\hline usilo & $\begin{array}{l}-0.001 \\
(0.013)\end{array}$ & $\begin{array}{c}0.003 \\
(0.013)\end{array}$ & & \\
\hline ump_ilo & $\begin{array}{c}0.062 * \\
(0.035)\end{array}$ & & & \\
\hline vix & $\begin{array}{l}-0.054 \\
(0.162)\end{array}$ & $\begin{array}{l}-0.166 \\
(0.145)\end{array}$ & $\begin{array}{l}-0.228 \\
(0.147)\end{array}$ & \\
\hline lsap_flow_gdp & & $\begin{array}{l}-0.166 \\
(0.218)\end{array}$ & & \\
\hline usi10_nonlsap & & & $\begin{array}{c}0.007 \\
(0.014)\end{array}$ & \\
\hline usilo_lsap & & & $\begin{array}{c}0.043 \\
(0.048)\end{array}$ & \\
\hline 2008.year & & & & $\begin{array}{l}-0.032 \\
(0.034)\end{array}$ \\
\hline 2009.year & & & & $\begin{array}{l}-0.058 \\
(0.048)\end{array}$ \\
\hline 2010.year & & & & $\begin{array}{l}-0.047 \\
(0.047)\end{array}$ \\
\hline 2011.year & & & & $\begin{array}{l}-0.040 \\
(0.043)\end{array}$ \\
\hline 2012.year & & & & $\begin{array}{l}-0.009 \\
(0.043)\end{array}$ \\
\hline 2013.year & & & & $\begin{array}{l}-0.033 \\
(0.044)\end{array}$ \\
\hline 2014.year & & & & $\begin{array}{l}-0.012 \\
(0.045)\end{array}$ \\
\hline 2015.year & & & & $\begin{array}{l}-0.050 \\
(0.046)\end{array}$ \\
\hline$N$ & 120 & 120 & 120 & 120 \\
\hline
\end{tabular}

